\title{
Review \\ Effects of Structure and Particle Size of Iron, Cobalt and Ruthenium Catalysts on Fischer-Tropsch Synthesis
}

\author{
Wenping Ma ${ }^{1, *}$ and Ajay K. Dalai ${ }^{2}$ \\ 1 Center for Applied Energy Research, University of Kentucky, 2540 Research Park Drive, \\ Lexington, KY 40511, USA \\ 2 Department of Chemical and Biological Engineering, University of Saskatchewan, \\ Saskatoon, SK S7N 5A9, Canada; ajay.dalai@usask.ca \\ * Correspondence: wenping.ma@uky.edu
}

Citation: Ma, W.; Dalai, A.K. Effects of Structure and Particle Size of Iron, Cobalt and Ruthenium Catalysts on Fischer-Tropsch Synthesis. Reactions 2021, 2, 62-77. https://doi.org/ $10.3390 /$ reactions 2010006

Academic Editor: Dmitry Yu. Murzin

Received: 7 December 2020

Accepted: 11 March 2021

Published: 19 March 2021

Publisher's Note: MDPI stays neutral with regard to jurisdictional claims in published maps and institutional affiliations.

Copyright: (c) 2021 by the authors. Licensee MDPI, Basel, Switzerland. This article is an open access article distributed under the terms and conditions of the Creative Commons Attribution (CC BY) license (https:// creativecommons.org/licenses/by/ $4.0 /)$.

\begin{abstract}
This review emphasizes the importance of the catalytic conversion techniques in the production of clean liquid and hydrogen fuels (XTF) and chemicals (XTC) from the carbonaceous materials including coal, natural gas, biomass, organic wastes, biogas and $\mathrm{CO}_{2}$. Dependence of the performance of Fischer-Tropsch Synthesis (FTS), a key reaction of the XTF/XTC process, on catalyst structure (crystal and size) is comparatively examined and reviewed. The contribution illustrates the very complicated crystal structure effect, which indicates that not only the particle type, but also the particle shape, facets and orientation that have been evidenced recently, strongly influence the catalyst performance. In addition, the particle size effects over iron, cobalt and ruthenium catalysts were carefully compared and analyzed. For all Fe, Co and Ru catalysts, the metal turnover frequency (TOF) for $\mathrm{CO}$ hydrogenation increased with increasing metal particle size in the small size region i.e., less than the size threshold 7-8 nm, but was found to be independent of particle size for the catalysts with large particle sizes greater than the size threshold. There are some inconsistencies in the small particle size region for Fe and Ru catalysts, i.e., an opposite activity trend and an abnormal peak TOF value were observed on a Fe catalyst and a Ru catalyst $(2 \mathrm{~nm})$, respectively. Further study from the literature provides deeper insights into the catalyst behaviors. The intrinsic activity of Fe catalysts $(10 \mathrm{~nm})$ at $260-300{ }^{\circ} \mathrm{C}$ is estimated in the range of $0.046-0.20 \mathrm{~s}^{-1}$, while that of the Co and $\mathrm{Ru}$ catalysts $(7-70 \mathrm{~nm})$ at $220^{\circ} \mathrm{C}$ are $0.1 \mathrm{~s}^{-1}$ and $0.4 \mathrm{~s}^{-1}$, respectively.
\end{abstract}

Keywords: carbonaceous materials; syngas; catalytic conversion; Fischer-Tropsch synthesis; cobalt; iron; ruthenium; metal turnover frequency; liquid fuel; hydrogen; chemicals

\section{Introduction}

To supply vast energy needs in the world while meeting more stringent environmental regulation to reduce the greenhouse gas emission, the global energy structure dominated by the fossil fuels such as oil, coal and natural gas is required to turn to low carbon system in the next thirty years [1]. For example, based on the US Energy Information Administration (EIA), energy consumption data (see Figure 1), world fossil fuels continuously dominate accounting for 77-84\% of energy consumptions by 2040 and $71.5 \%$ by 2050 through the reduction of oil and coal usage by 3-7\% points. Meanwhile, the renewable energy including nuclear and hydro energy accounts for $17 \%$ in 2016 and increase to $22.3 \%$ and $28 \%$ by 2040 and 2050, respectively. At the present consumption rate, it produces about 30 billion tons of $\mathrm{CO}_{2}$ per year, mainly from power plants and heavy industries. Therefore, cleaner utilization of the fossil fuels; development of renewable energy primarily based on solar, wind and hydropower; $\mathrm{CO}_{2}$ utilization technologies; and increase in efficiency of chemical processes will play important role in reducing $\mathrm{CO}_{2}$ emission. However, despite an expected increase in the fraction of the renewable energy and/or $\mathrm{H}_{2}$ energy, catalytic conversion of the abundant world reserved and newly produced carbonaceous resources $(X)$ including coal, natural gas, biomass, organic wastes, biogas and $\mathrm{CO}_{2}$ to liquid and hydrogen fuels 
(XTF) and chemicals (XTC), continues to play important role in carbon utilization, carbon neutrality and supplying clean energy. Moreover, the renewable technologies that are currently being developed, cannot achieve the required scale in the short to medium term. For example, the renewable energy, if excludes the nuclear and hydro power, only can provide $5-11 \%$ of energy required in the world. This scenario becomes more prominent in the nations having abundant carbonaceous resources, such as China, India, South Africa, USA, and European countries. Furthermore, when the advanced renewable technologies and the technologies of $\mathrm{CO}_{2}$ capture, sequestration and utilization are developed and commercialized in the future, it could lead to significantly lower the cost of gasification of various carbonaceous materials to syngas and make the XTF/XTC technologies to be more attractive in the clean utilization of the abundant carbon resources.

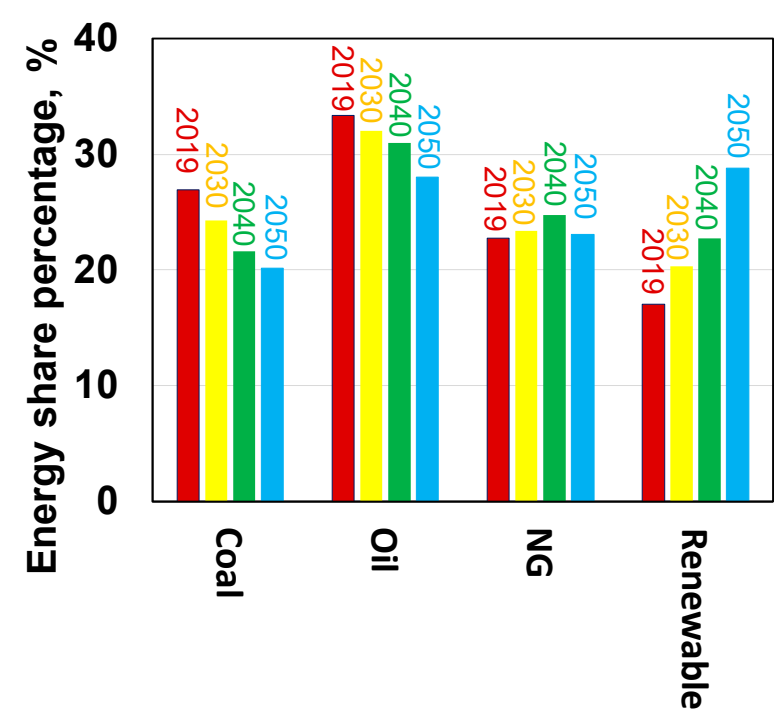

Figure 1. World primary Energy and projection (data from [1]).

One of the heart of the XTF/XTC technologies is the Fischer-Tropsch synthesis (FTS) reaction, which converts a syngas mixture derived from various carbonaceous materials to hydrocarbons and alcohols (Equations (1)-(3)), meanwhile, a side reaction of water gas shift (WGS) is usually accompanied (Equation (4)).

$$
\begin{gathered}
\mathrm{CO}+\mathrm{H}_{2} \rightarrow \mathrm{C}_{\mathrm{n}} \mathrm{H}_{2 \mathrm{n}+2}+\mathrm{H}_{2} \mathrm{O}(\Delta \mathrm{H}=-165 \mathrm{~kJ} / \mathrm{mol}) \\
\mathrm{CO}+\mathrm{H}_{2} \rightarrow \mathrm{C}_{\mathrm{n}} \mathrm{H}_{2 \mathrm{n}}+\mathrm{H}_{2} \mathrm{O}(\Delta \mathrm{H}=-165 \mathrm{~kJ} / \mathrm{mol}) \\
\mathrm{CO}+\mathrm{H}_{2} \rightarrow \mathrm{C}_{\mathrm{n}} \mathrm{H}_{2 \mathrm{n}+2} \mathrm{O}+\mathrm{H}_{2} \mathrm{O}(\Delta \mathrm{H}=-165 \mathrm{~kJ} / \mathrm{mol}) \\
\mathrm{CO}+\mathrm{H}_{2} \mathrm{O}=\mathrm{CO}_{2}+\mathrm{H}_{2}(\Delta \mathrm{H}=-42 \mathrm{~kJ} / \mathrm{mol})
\end{gathered}
$$

This technology, because of its importance in industry, has received extensive attention since its discovery in 1923, which led to many FT plants in the world based on large number of fundamental and applied studies [2,3]. The most common catalysts for FTS reaction are the transition metal catalysts i.e., iron, cobalt and Ruthenium, among them the Fe and Co catalysts are largely researched and commercialized because of their high activity, high selectivity to heavy hydrocarbons, and low cost [2-5]. For example, iron and cobalt catalysts can produce hydrocarbons with a chain growth probability over 0.9 , and $\mathrm{C}_{5+}$ selectivity surpasses $88 \%$ when operated at low temperature $\leq 230{ }^{\circ} \mathrm{C}$ in a slurry phase reactor [5]. In case of Ru based catalysts, many fundamental studies have been also carried out irrespective of the extremely high cost of Ru [6-10]. The Ru catalysts have been reported to be most active, high resistant to water and oxygenate-containing environment, and favor the production of high molecular weight hydrocarbons. This, in turn, results in a decreased cost of FTS fuels production, which is an important requisite to successfully 
convert biomass-derived syngas into hydrocarbons [6,7]. However, in spite of numerous studies on this topic, there is still no clear picture what the catalysts' potential performance can reach or what the intrinsic activities per site of $\mathrm{Fe}, \mathrm{Co}$ and $\mathrm{Ru}$ are.

Among the vast number of studies on the FTS reaction, there is one important topic regarding the dependence of catalyst performance on catalyst structure (crystal and size). In this review, recent fundamental development in the aspect over $\mathrm{Fe}$, $\mathrm{Co}$ and Ru catalysts are discussed, results among different studies are critically reviewed and compared. It is expected that through better understanding the structure effects and the reaction performance of $\mathrm{Fe}, \mathrm{Co}$ and Ru catalysts, deep insights into catalysis on the catalysts' surface and catalysts' potential activity can be provided, which should be helpful for the design of new generation of catalysts with super activity, stability and selectivity.

\section{Results and Discussion}

\subsection{Catalyst Crystal Structure and Catalytic Performance}

The crystal structure of the FTS catalysts plays crucial role in controlling FTS performance. In case of iron catalyst, several iron carbides with different structures, for example $\theta-\mathrm{Fe}_{3} \mathrm{C}, \chi-\mathrm{Fe}_{5} \mathrm{C}_{2}$, and $\varepsilon-\mathrm{Fe}_{2} \mathrm{C} / \varepsilon^{\prime}-\mathrm{Fe}_{2} \cdot 2 \mathrm{C}$, and $\mathrm{Fe}_{7} \mathrm{C}_{3}$ (Figure 2a-d), have been identified as active phases for the FTS reaction [11-15]. Dry [11] has reported phase change in iron for an iron catalyst that was operated in a fluidized bed reactor at $327^{\circ} \mathrm{C}$. The metallic $\mathrm{Fe}$ was quickly converted to $\theta-\mathrm{Fe}_{3} \mathrm{C}$ and $\chi-\mathrm{Fe}_{5} \mathrm{C}_{2}$, while $\mathrm{Fe}_{7} \mathrm{C}_{3}$ (Eckstrom and Adcock) was observed at very high pressure i.e., $>6.0 \mathrm{MPa}$. No clear correlation between iron catalyst and carbide phase was reported. In the study of Smit et al. [12], the stability and reactivity of iron carbide phases $(\theta, \chi$ and $\varepsilon)$ in FTS catalysts as a function of relevant reaction conditions were studied experimentally and theoretically. These authors have reported that thermodynamic stability of the carbide phases and the transformation among the carbides are highly dependent on the carbon chemical potential $(\mu \mathrm{c})$ imposed by the chemical (gas phase) surroundings. Increasing temperature from 150 to $450{ }^{\circ} \mathrm{C}$ led to linearly decreasing of the $\mu \mathrm{c}$, while it increased with increasing pressure from 1 to $2.0 \mathrm{MPa}$ or $\mathrm{CO} / \mathrm{H}_{2}$ ratio from 0.25 to 0.45 . The trigonal prismatic (TP) carbides such as $\theta-\mathrm{Fe}_{3} \mathrm{C}, \gamma-\mathrm{Fe}_{5} \mathrm{C}_{2}$, and $\mathrm{Fe}_{7} \mathrm{C}_{3}$ are reported to be more stable than the octahedral carbides $(\mathrm{O}) \varepsilon-\mathrm{Fe}_{2} \mathrm{C}$ and $\eta-\mathrm{Fe}_{2} \mathrm{C}$ at lower $\mu_{\mathrm{C}}$ (higher temperature, lower $\mathrm{CO}$ pressure). At very low $\mu_{\mathrm{C}}(-7.7 \mathrm{eV}) \theta-\mathrm{Fe}_{3} \mathrm{C}$ phase is more stable than $\varepsilon-\mathrm{Fe}_{2 \cdot 2} \mathrm{C}$, and $\theta-\mathrm{Fe}_{3} \mathrm{C}$ becomes more stable with respect to $\gamma-\mathrm{Fe}_{5} \mathrm{C}_{2}$ at low $\mu_{\mathrm{C}}(-7.6 \mathrm{eV})$ conditions; however, $\mathrm{Fe}_{7} \mathrm{C}_{3}$ was reported to be stable with respect to $\gamma-\mathrm{Fe}_{5} \mathrm{C}_{2}$ at higher $\mu_{\mathrm{C}}(\sim 7.25 \mathrm{eV})$. The detailed carbides transformation is outlined in Figure $2 \mathrm{~b}$. Davis [13] characterized $100 \mathrm{Fe} / 3.7 \mathrm{Si} / 0.7 \mathrm{~K}$ catalyst that was collected at different time period during the FTS at $270{ }^{\circ} \mathrm{C}, 1.3 \mathrm{MPa}, \mathrm{H}_{2} / \mathrm{CO}=0.7$ and $10-90 \% \mathrm{CO}$ conversion. After syngas activation followed by $100 \mathrm{~h}$ of FTS reaction, the iron catalyst showed low activity (5-20\%CO conversion) and then it was re-pretreated by CO for $24 \mathrm{~h}$. The iron catalyst activity was increased significantly after it returned to normal FTS condition, and a stable $\mathrm{CO}$ conversion of $90 \%$ was obtained in the next $300 \mathrm{~h}$, which was accompanied by mainly $\mathrm{Fe}_{3} \mathrm{O}_{4}$ in the first $100 \mathrm{~h}$ and about $40 \%$ iron carbides and $60 \% \mathrm{Fe}_{3} \mathrm{O}_{4}$ in the remaining $300 \mathrm{~h}$ (Figure 2c). This study likely indicates that catalyst activity is associated with carbide phase (s). Recently, Change et al. [14] was able to show significant difference in the activities of various iron carbides. The group designed and studied the activity of different carbides on a model $\mathrm{Fe} / \mathrm{SiO}_{2}$ catalyst at $260^{\circ} \mathrm{C}, 3 \mathrm{MPa}$ and $\mathrm{H}_{2} / \mathrm{CO}=2$ in a micro-fixed bed reactor. Different iron carbides including $\varepsilon-\mathrm{Fe}_{2} \mathrm{C}, \mathrm{Fe}_{7} \mathrm{C}_{3}$, and $\chi-\mathrm{Fe}_{5} \mathrm{C}_{2}$ were synthesized by treating the calcined $\mathrm{Fe} / \mathrm{SiO}_{2}$ catalyst with different gas atmospheres $\left(\mathrm{CO}, \mathrm{H}_{2}\right.$, or syngas) at $300{ }^{\circ} \mathrm{C}$. The intrinsic FTS activity of $\mathrm{Fe}_{7} \mathrm{C}_{3}$ was found to be the highest with a turnover frequency (TOF) of $4.59 \times 10^{-2} \mathrm{~s}^{-1}$, while $\chi-\mathrm{Fe}_{5} \mathrm{C}_{2}$ and $\varepsilon-\mathrm{Fe}_{2} \mathrm{C}$ had only about $1 / 3$ of the activity (Figure 2d); meanwhile, $\varepsilon-\mathrm{Fe}_{2} \mathrm{C}$ yielded the lowest methane selectivity. 

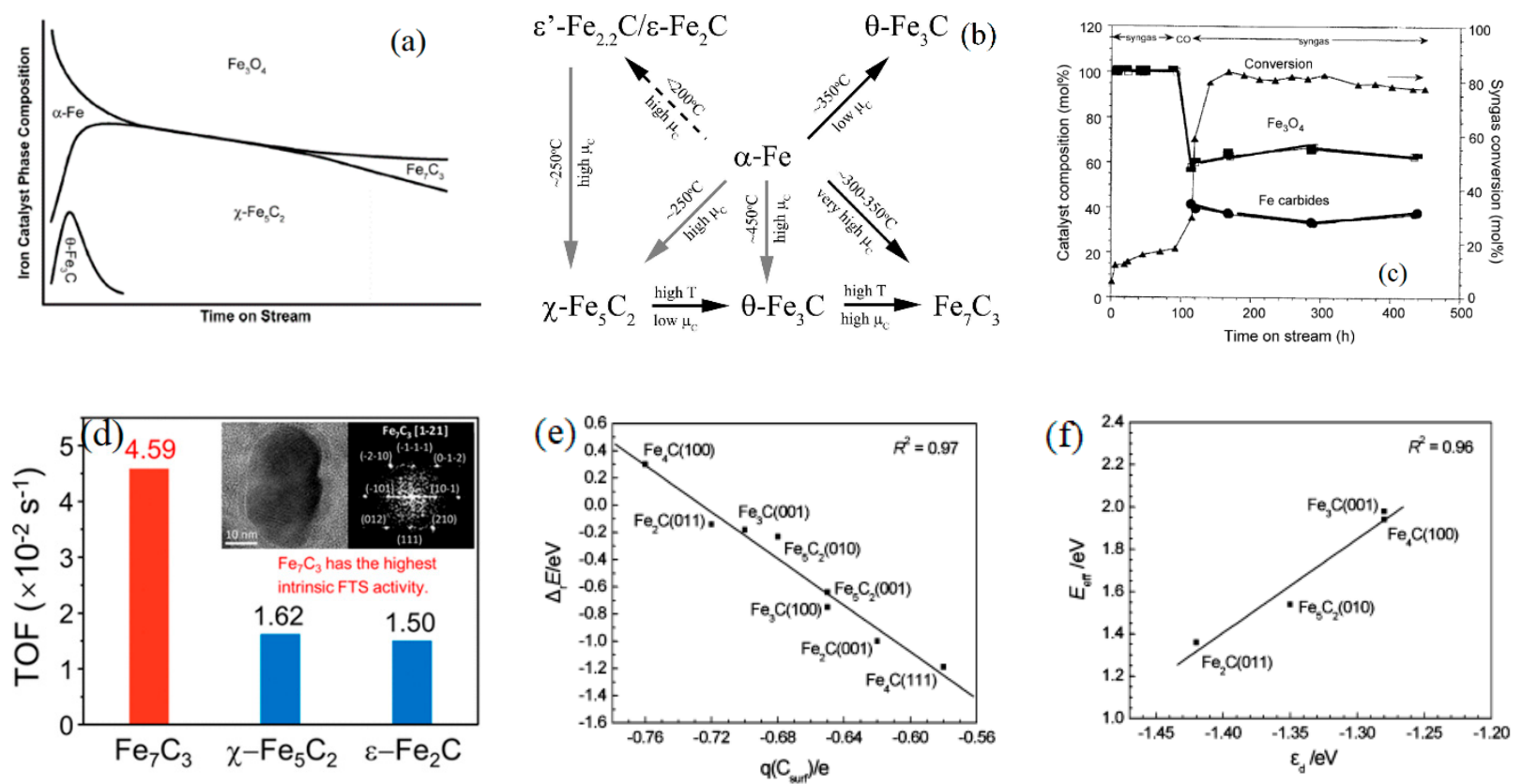

Figure 2. (a) Iron carbide structures vary with reaction time (from [11]), (b) Iron carbide structures and thermodynamics (reproduced with permission from [12] Copyright 2010, Elsevier), (c) iron phase composition and activity (reproduced with permission from [13] Copyright 2009, Elsevier), (d) Activity as a function of iron carbide type (reproduced with permission from [14] Copyright 2018, ACS), (e) bottom-middle and (f) Relationships between reaction energy $(\Delta \mathrm{rE})$ of $\mathrm{CH}_{4}$ formation and Mulliken charge $(q)$ of the surface $\mathrm{C}$ atom as well as effective barrier (Eeff) of $\mathrm{CH}_{4}$ formation and d-band center ( $\varepsilon$ d) of the surface. (reproduced with permission from [16] Copyright 2009, ACS).

Quantum computation i.e., ab-initio, kinetic Monte Carlo (kMC) and density functional theory (DFT) provided deeper insights into the catalysis phenomena on active metal surface. It was found that the catalyst activity also varied with facet and dimension, corner, edge of active sites. Huo et al. [16] used DFT approach to elucidate why methane formation energy varied with carbide phases (i.e., high $\mathrm{CH}_{4}$ formation rate on $\mathrm{Fe}_{2} \mathrm{C}(011)$ and $\mathrm{Fe}_{5} \mathrm{C}_{2}(010)$ surface, and inactive $\mathrm{CH}_{4}$ rate on $\mathrm{Fe}_{3} \mathrm{C}(001)$ and $\mathrm{Fe}_{4} \mathrm{C}(100)$ surface). These authors found that reaction energy and effective barrier of $\mathrm{CH}_{4}$ formation have a linear relationship with the charge of the surface $C$ atom and the d-band center of the surface (Figure 2e,f). Similar results were also reported on Co and Ru surface by van Santen et al. [17]. CO dissociation energy at dense terraces surfaces of Co or Ru can be much higher than that of step-edge sites ( $200 \mathrm{vs} .<100 \mathrm{~kJ} / \mathrm{mol}$ ), which requires a step-edge site on metals for $\mathrm{CO}$ activation.

FTS performance of cobalt catalyst strongly depends on cobalt crystal structure as well. Two types of cobalt metal structures (active phases), i.e., face centered cubic (fcc), hexagonal close packed (hcp), have been reported, which were synthesized under different pretreatment conditions, for example, $\mathrm{Co}$-fcc was formed on various $\mathrm{Al}_{2} \mathrm{O}_{3}, \mathrm{SiO}_{2}$ and $\mathrm{TiO}_{2}$ supported catalysts using hydrogen reduction at high temperature over $350{ }^{\circ} \mathrm{C}$, while the hexagonal close packed cobalt metal (Co-hcp) was preferentially formed when the cobalt catalysts were treated by hydrogen at low temperature below $330^{\circ} \mathrm{C}$, or by syngas reduction or by carburation followed by hydrogenation i.e., $\mathrm{H}_{2}-\mathrm{CO}-\mathrm{H}_{2}$ pretreatment steps between 230-350 ${ }^{\circ} \mathrm{C}$ [18-24]. When these cobalt phases are exposed to typical FTS conditions, the Co-hcp and Co-fcc display much different intrinsic activity [19-22,24]. Ducreux et al. [19] prepared $\mathrm{SiO}_{2}, \mathrm{Al}_{2} \mathrm{O}_{3}$ and $\mathrm{TiO}_{2}$ supported $11-13 \% \mathrm{Co}$ catalysts with and without $0.45 \% \mathrm{Ru}$ in order to explore a possible relationship between microstructure of the cobalt catalysts and catalytic activity. These authors observed complete reduction of $\mathrm{CoO}$ to cobalt metal by $\mathrm{H}_{2}$ on $\mathrm{Al}_{2} \mathrm{O}_{3}$ above $550{ }^{\circ} \mathrm{C}$, while it was completed on $\mathrm{Co} / \mathrm{SiO}_{2}$ at lower temperatures. In both cases, mixed $\mathrm{Co}$ (hcp) and (fcc) cobalt were formed, but low temperatures tend to form high fraction $\mathrm{Co}(\mathrm{hcp})$. When the catalysts were reduced by $\mathrm{CO}$ at $230^{\circ} \mathrm{C}$ for $15 \mathrm{~h}$ followed 
by $\mathrm{H}_{2}$ reduction at the same temperature, cobalt carbide $\left(\mathrm{Co}_{2} \mathrm{C}\right)$ was decomposed and more $\mathrm{Co}$ (hcp) stacking was detected. Examining the activity of different $\mathrm{Co} / \mathrm{Al}_{2} \mathrm{O}_{3}$ and $\mathrm{Co} / \mathrm{SiO}_{2}$ catalysts indicated that activity of the catalyst, most enriched in Co hcp stacking, was found to be $50 \%$ higher than the catalyst most enriched in Co fcc stacking on $\mathrm{Al}_{2} \mathrm{O}_{3}$ support $\left(\mathrm{X}_{\mathrm{CO}}=30\right.$ to $45 \%$, Figure 3a), but the activity difference between the two cobalt phases was enlarged by more than triple fold on a $\mathrm{Ru}$ promoted $\mathrm{Co} / \mathrm{SiO}_{2}$ supported catalyst $\left(\mathrm{X}_{\mathrm{CO}}=8\right.$ to 34\%, Figure 3b). Later, Sadeqzadeha et al. [21] and Gnanamani et al. [22] used similar approach i.e., using pure $\mathrm{H}_{2}$ reduction at $350^{\circ} \mathrm{C}$, or $\mathrm{CO}\left(230{ }^{\circ} \mathrm{C}\right)-\mathrm{H}_{2}\left(230^{\circ} \mathrm{C}\right)$ or $\mathrm{H}_{2}$ $\left(350{ }^{\circ} \mathrm{C}\right)-\mathrm{CO}\left(230^{\circ} \mathrm{C}\right)-\mathrm{H}_{2}\left(230^{\circ} \mathrm{C}\right)$ reduction procedures to prepare Co-hcp and Co-fcc on $0.1 \% \mathrm{Pt}-25 \% \mathrm{Co} / \mathrm{Al}_{2} \mathrm{O}_{3}$ and $20 \% \mathrm{Co} / \mathrm{SiO}_{2}$ catalysts, respectively. Activity of the Co-hcp rich catalyst was over one time higher than the Co-fcc rich $25 \% \mathrm{Co}-0.1 \% \mathrm{Pt} / \mathrm{Al}_{2} \mathrm{O}_{3}$ catalyst (Co STY at $220^{\circ} \mathrm{C}, 2.0 \mathrm{MPa}, \mathrm{H}_{2} / \mathrm{CO}=2.0$, and $40 \% \mathrm{CO}$ conversion: 0.032 to $0.072 \mathrm{~s}^{-1}$, Figure $3 \mathrm{c}$ ), while the TOF was only about $32 \%$ higher on $20 \% \mathrm{Co} / \mathrm{SiO}_{2}\left(\mathrm{CO}\right.$ rate at $200{ }^{\circ} \mathrm{C}, 1.99 \mathrm{MPa}$, $\mathrm{H}_{2} / \mathrm{CO}=2.0$, and $3.0 \mathrm{NL} /$ gcat $/ \mathrm{h}: 0.024$ to $0.034 \mathrm{~mol} /$ gcat $/ \mathrm{h}$, Figure $3 \mathrm{~d}$ ). Liu et al. [25] reported lower activation energy for the CO activation on Co (hcp) than Co (fcc), which is consistent well with the higher activity of the Co (hcp) structure. It is likely that the Ru and $\mathrm{Pt}$ promoters benefit the formation of Co-hcp phase. Moreover, the two cobalt phases gave different hydrocarbon selectivity, Co-hcp yielded low $\mathrm{CH}_{4}$ and high $\mathrm{C}_{5+}$ selectivity [22], indicating relatively high hydrogenation barrier but low $\mathrm{C}-\mathrm{C}$ coupling energy on the Cohcp phase. Cobalt carbide is another different Co phase, which was reported to be inactive for FTS reaction [21,26,27]. However, Ding et al. [28,29] studied the synthesis of $C_{1}-C_{18}$ alcohols from syngas over $\mathrm{La}-\mathrm{Co} / \mathrm{AC}$ catalysts at $222{ }^{\circ} \mathrm{C}, 3 \mathrm{MPa}, \mathrm{H}_{2} / \mathrm{CO}=2.0$. High alcohol selectivity i.e., $37-39 \%$ was reported under the conditions, which was attributed to La promoting the formation of $\mathrm{CO}_{2} \mathrm{C}$ that benefited the alcohol formation.
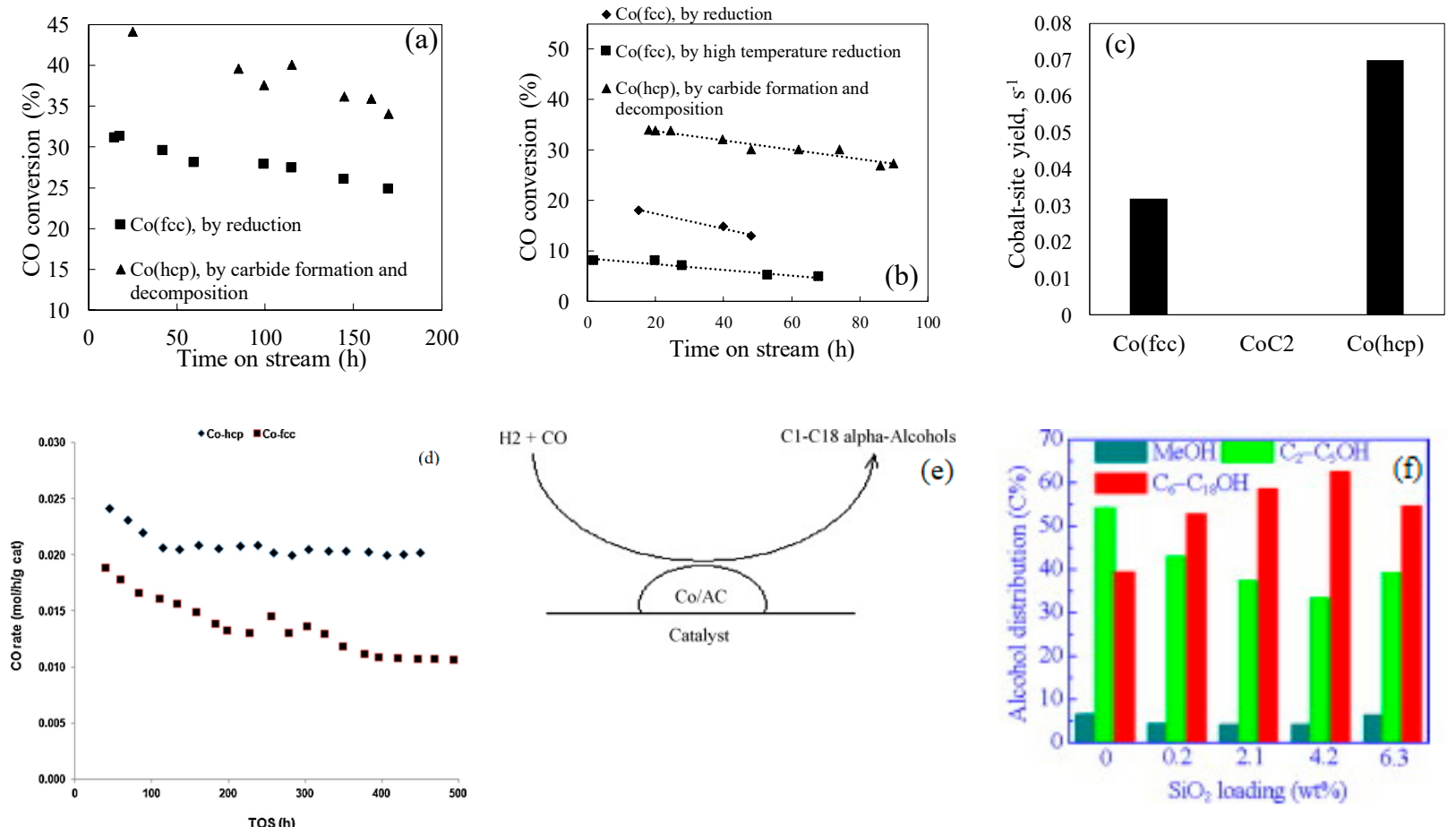

Figure 3. (a) FT activity of $\mathrm{Co} / \mathrm{Al}_{2} \mathrm{O}_{3}$ catalyst (from [19]), (b) FT activity of Co/ $\mathrm{SiO}_{2}$ catalyst (from [19]), (c) FT activity of $\mathrm{Co} / \mathrm{Al}_{2} \mathrm{O}_{3}$ catalyst (reproduced with permission from [21] Copyright 2011, Elsevier), (d) $\mathrm{FT}$ activity of $\mathrm{Co} / \mathrm{SiO} \mathrm{O}_{2} \mathrm{catalyst}$ (reproduced with permission from [22] Copyright 2013, Elsevier). (e) $\mathrm{C}_{1}-\mathrm{C}_{18}$ alcohols formation on Co/AC catalyst (reproduced with permission from [28] Copyright 2009, Elsevier), (f) $C_{1}-C_{18}$ alcohols formation on Co/AC catalyst (reproduced with permission from [29] Copyright 2015, Elsevier). 
In case of Ru FTS catalyst, the same face centered cubic and hexagonal close packed $\mathrm{Ru}$ metal structures as cobalt catalyst have been reported. Interestingly, the Ru catalysts show distinctive reverse activity trend with the Ru phases. Both experiment and theoretical DFT calculation by Li et al. [30] consistently indicated that the activity of the Ru-fcc was significantly higher than the Ru-hcp at the same particle size $6.8 \mathrm{~nm}, \mathrm{CO}$ rate at $160{ }^{\circ} \mathrm{C}$ was found to be 37.8 vs. $11.8 \mathrm{molCO} / \mathrm{mol}-\mathrm{Ru} / \mathrm{h}$ for the Ru-fcc and Ru-hcp, respectively. This could be due to the fact that fcc and hcp Ru bulks exhibited very different morphologies, the fcc Ru was octahedron like populated mainly by close-packed (111) facets, and the hcp $\mathrm{Ru}$ was a dihedral-like shape populated mainly by open facets, which gave greater amounts of Ru-fcc open facets and more active sites for $\mathrm{CO}$ dissociation, even though the intrinsic activity of hcp phase is higher than fcc due to the low energy barrier for $\mathrm{CO}$ dissociation on the hcp phase on both Co and Ru metals (Co-hcp 1.07 ev vs. Co-fcc 1.47 ev [25], Ru-hcp 1.0 ev vs. Ru-fcc 1.2ev) [30].

It should be noted that the structure of the catalysts that plays crucial roles on the FTS reaction are not only controlled by pretreatment conditions [14,18-24], but also are adjusted greatly by promoters and supports/binders [31-35]. For example, K [31,32] and Mn [33,34] were reported to promote and suppress iron carburization, respectively, leading to different amounts of iron carbides. Incorporation of $\mathrm{SiO}_{2}$ to iron catalysts restrained carburization of iron catalysts but promoted heavier hydrocarbons formation and catalyst stability [35]. Most recently, $\mathrm{Lu}$ et al. [15] reported that $\mathrm{SiO}_{2}$ or $\mathrm{Al}_{2} \mathrm{O}_{3}$ supports showed electronic impact on iron atomic status, resulting in an improved amounts of $\mathrm{C}$-rich iron carbide active phase $\left(\varepsilon-\mathrm{Fe}_{2} \mathrm{C}\right)$ that was claimed to have more positive roles on the activity of supported $\mathrm{Fe} / \mathrm{Al}_{2} \mathrm{O}_{3}$ and $\mathrm{Fe} / \mathrm{SiO}_{2}$ catalysts under $280{ }^{\circ} \mathrm{C}, 1 \mathrm{MPa}, \mathrm{H}_{2} / \mathrm{CO}=1$, and $10 \mathrm{NL} / \mathrm{g}$-cat $/ \mathrm{h}$. The similar notable support effects on Ru catalyst have also been evidenced $[6,36,37]$. The discussion of additional support effects on the properties of FTS catalysts is beyond the scope of this review.

In summary, the crystal structure (phase and morphology) of iron, cobalt and Ru catalysts, that can be controlled by adjusting pretreatment conditions, supports/binders and promoters, remarkably impact on FTS performance. The influence are very complicated not only because of many active phases of each metal present during FTS, but also because of different morphologies formed including shape, facet and orientation, edge and corner on each phase, which could change amounts of active sites, and CO adsorption mechanism (multiple reaction mechanisms could occur on each catalyst surface), consequently leading to different catalyst activity, selectivity and stability $[16,25,30]$. Further improving FTS catalyst performance towards better stability and higher heavier hydrocarbon yield is challenge and this requires tremendous efforts including experimental optimization of the catalyst structure coped with the advanced technique of molecular-level catalyst design i.e., DFT.

\subsection{Metal Particle Size Effects on Catalyst Performance}

Metal particle size effect, which is related to the structure sensitiveness of the catalyst, has been extensively studied in the past decades [8,38-75]. Since Boudart et al. [38] proposed the concept and assumed FTS is a structure insensitive reaction, it took long time to amend the conclusion. Iglesia's group used Co or Ru catalysts with the metal particle size over $8 \mathrm{~nm}$ and had drawn the conclusion of independent of catalysts performance on the metal particle size/dispersion (structure insensitive) [8,40,41]. This conclusion is not in line with the earlier particle size studies on iron catalysts by Vannice [42] and Bartholomew groups [43], which noticed lower activity on smaller Fe particles in less than $9 \mathrm{~nm}$ particles. A conclusive cobalt particle size effect on FTS has not been made until de Jong group [44] studied the effect in a tiny to big particle size range $(2.6-27 \mathrm{~nm})$. In contrast, the Fe and $\mathrm{Ru}$ particle size effects are less consistent even though it has attracted significant interests from academics. The review and discussion on the recent exploration of the particle size effects on $\mathrm{Co}, \mathrm{Fe}$ and Ru catalysts are given below. Important insights into the particle size effects are also provided. 


\subsubsection{Examples of Cobalt Catalyst}

As mentioned above, Iglesia [41] found that the CO turnover frequency (TOF) remained constant at $0.021 \mathrm{~s}^{-1}$ (independent of Co dispersion and support type) in the Co particle size range of $8-96 \mathrm{~nm}$ under $200{ }^{\circ} \mathrm{C}, 2 \mathrm{MPa}, \mathrm{H}_{2} / \mathrm{CO}=2.05$, and $55-65 \% \mathrm{CO}$ conversion (Figure 4a), apparently, the effect of the smaller Co size less than $8 \mathrm{~nm}$ was ignored. A comprehensive Co particle size effect study was represented by the recent study of Bezemer et al. [44], who used 1.0-22\%Co/CNF (Carbon Nanofiber), prepared by impregnation (IWI) and homogeneous deposition precipitation (HDP), that yielded 2.6-27 nm Co particles. These authors reported that Co TOF was only $0.0014 \mathrm{~s}^{-1}$ at $2.6 \mathrm{~nm}$, which increased with increasing Co particle size up to $8.0 \mathrm{~nm}$, reaching at a constant value of $0.023 \mathrm{~s}^{-1}$ at $210{ }^{\circ} \mathrm{C}, 3.5 \mathrm{MPa}$, and $\mathrm{H}_{2} / \mathrm{CO}=2.0$ (Figure $4 \mathrm{~b}$ ). Therefore, both the Iglesias and Bezemer groups found that $\mathrm{Co}$ TOF was independent of Co particle size for the catalysts with sizes greater than $8 \mathrm{~nm}$ at typical FT conditions. $\mathrm{C}_{5+}$ selectivity and olefin selectivity were reported to increase with increasing Co particle size up to $16 \mathrm{~nm}$, accompanied with a decrease in $\mathrm{CH}_{4}$ selectivity. In several subsequent studies on Co particle size effect, Breejen et al. [45] used the steady-state isotopic transient kinetic analysis (SSITKA) technique to elucidate nature of the small Co size effect $(<8 \mathrm{~nm})$. It was postulated that small particles block edge/corner sites and show a low intrinsic activity at the small terraces; furthermore, small Co particles were assumed to possess higher $\mathrm{H}_{2}$ coverages, leading to higher $\mathrm{CH}_{4}$ selectivity. Holmen et al. [46] obtained the maximum $\mathrm{C}_{5+}$ selectivity (84.2\%) under $210{ }^{\circ} \mathrm{C} 2.0 \mathrm{MPa}, \mathrm{H}_{2} / \mathrm{CO}=2.1$, and $43-46 \% \mathrm{CO}$ conversion at an average Co particle size of $8 \mathrm{~nm}$ on $\mathrm{Al}_{2} \mathrm{O}_{3}$ support, above $10 \mathrm{~nm}, \mathrm{C}_{5+}$ selectivity was nearly unchanged. Prieto et al. [47] also reported the two regions of Co particle size i.e., $<>10 \mathrm{~nm}$, that showed different activity trends over $10 \% \mathrm{Co} / \mathrm{ITQ}-2$ (zeolite) catalysts. The maximum and constant $\operatorname{TOF}\left(0.0086 \mathrm{~s}^{-1}\right)$ at $220^{\circ} \mathrm{C}, 2 \mathrm{MPa}, \mathrm{H}_{2} / \mathrm{CO}=2$, and $10 \% \mathrm{CO}$ conversion was observed at the Co size range of 10-141 nm. Small cobalt particles $(5.6-10 \mathrm{~nm})$ showed lower activity, that was ascribed to the formation of partially oxidized Co species $\left(\mathrm{Co}^{\mathrm{d}+}\right)$ at the Co-support interface. Gavrilovic et al. [62] and Park et al. [64] also conducted Co particle size effect in 6-13 nm and 3-16 nm ranges using $0.5 \% R e 20 \% \mathrm{Co} / \mathrm{Al}_{2} \mathrm{O}_{3}$ and $5 \% \mathrm{Co} / \mathrm{Al}_{2} \mathrm{O}_{3}$, respectively. Similar activity and $\mathrm{C}_{5+}$ selectivity trends were obtained in the cobalt particle size ranges smaller and larger than $9.3-10 \mathrm{~nm}$.
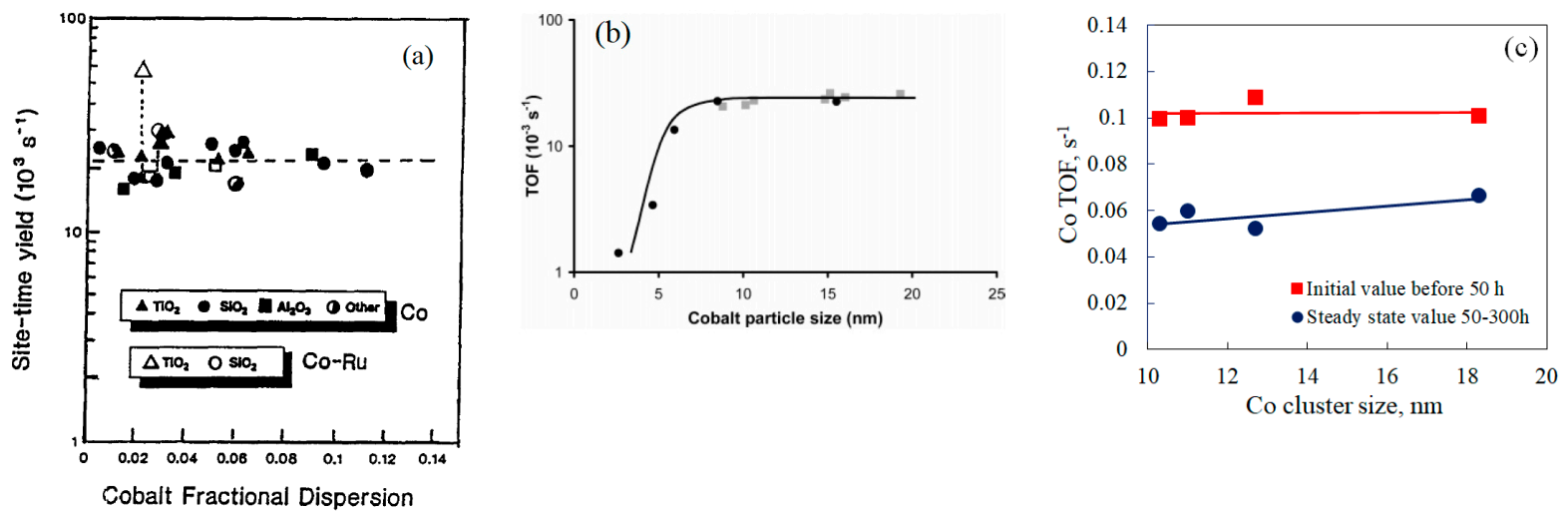

Figure 4. (a) Effect of cobalt dispersion (ratio of surface $\mathrm{Co}$ to total $\mathrm{Co}$ atoms), $200{ }^{\circ} \mathrm{C}, 2.0 \mathrm{MPa}, \mathrm{H}_{2} / \mathrm{CO}=2.05,55-65 \% \mathrm{CO}$ conversion, $\mathrm{C}_{5+}$ selectivity $>80 \%$ (reproduced with permission from [41] Copyright 1997, Elsevier), (b) the influence of cobalt particle size on the TOF at $3.5 \mathrm{MPa}, 210^{\circ} \mathrm{C}$ and $\mathrm{H}_{2} / \mathrm{CO}=2.0$ (reproduced with permission from [44] Copyright 2006, Elsevier), (c) the influence of cobalt particle size on $\mathrm{Co} \mathrm{TOF}$ at $2.2 \mathrm{MPa}, 220^{\circ} \mathrm{C}$ and $\mathrm{H}_{2} / \mathrm{CO}=2.1$ (data from [48]).

An attention that must be paid is that the Co TOF varies significantly in different studies although researchers reach a consensus on the Co particle size effect. Iglesia [41] obtained an apparent Co TOF of $0.021 \mathrm{~s}^{-1}$ on various supported catalysts at $200{ }^{\circ} \mathrm{C}$ and 2.0 MPa in a fixed bed reactor, which is equivalent to $0.05 \mathrm{~s}^{-1}$ at $220^{\circ} \mathrm{C}$; the TOF value of Bezemer et al. [44] on CNF support at $210^{\circ} \mathrm{C}$ and $3.5 \mathrm{MPa}$ was $0.023 \mathrm{~s}^{-1}$, equivalent 
to $0.038 \mathrm{~s}^{-1}$ at $220^{\circ} \mathrm{C}$. Prieto et al. [47] reported the lowest Co TOF values of $0.0086 \mathrm{~s}^{-1}$ on Co/ITQ-2-zeolite under similar process conditions. In the study of Park et al. [64], a high cobalt initial TOF value $(24-40 \mathrm{~h})$ of $0.08 \mathrm{~s}^{-1}$ was obtained on a $5 \% \mathrm{Co} / \mathrm{Al}_{2} \mathrm{O}_{3}$ catalysts with mean cobalt particle size of $9.3 \mathrm{~nm}$ under $220{ }^{\circ} \mathrm{C}, 1.0 \mathrm{MPa}, \mathrm{H}_{2} / \mathrm{CO}=2.0$ and $30 \%$ $\mathrm{CO}$ conversion. Recently, Ma et al. [48] studied the effects of $0.5 \%$ noble metals (Pt, $\mathrm{Re}$, $\mathrm{Ru}$ ) on $25 \% \mathrm{Co} / \mathrm{Al}_{2} \mathrm{O}_{3}$ catalyst for FTS reaction under $220{ }^{\circ} \mathrm{C}, 2.0 \mathrm{MPa}, \mathrm{H}_{2} / \mathrm{CO}=2.1$ and $50 \%$ CO conversion in 1-L CSTR. By taking into account the chemisorption results on the cobalt catalysts, they obtained a high initial Co TOF of $0.1 \mathrm{~s}^{-1}$ in the cobalt particle size range 10.0-18.6 $\mathrm{nm}$ on the $\mathrm{Pt}, \mathrm{Re}$, $\mathrm{Ru}$ promoted and unpromoted $25 \% \mathrm{Co} / \mathrm{Al}_{2} \mathrm{O}_{3}$ catalysts (Figure 4c), which is in line with Park's study. At steady state, the Co TOF based on the initial Co dispersion was reduced to $0.05-0.067 \mathrm{~s}^{-1}$, which is close to the apparent TOF values in the study of Iglesia [41], but much greater than that in the studies of Bezemer and Prieto.

Several reasons are proposed to be responsible for the discrepancy: (1) support/transport effect, (2) deactivation, and (3) experimental error. The cobalt initial TOF value of $0.1 \mathrm{~s}^{-1}$ reported by $\mathrm{Ma}$ et al. [48] was obtained in a CSTR using fine particles i.e., 45-90 $\mu \mathrm{m}$, thus the value reflects the intrinsic Co activity because the internal and external mass transfer were eliminated and the deactivation was ignored; while the studies of Iglesia [41], Bezemer et al. [44] and Prieto et al. [47] employed large catalyst particles i.e., $170 \mathrm{~mm}$, $500 \mathrm{~mm}$ or $250-400 \mathrm{~mm}$, respectively, which included the mass transfer effect in the reaction, consequently, it decreased the catalysts' activities. However, the activity difference resulted by the difference in mass transfer of the 170-500 $\mathrm{mm}$ particles is estimated to be less than $17-30 \%$ at initial and steady state periods in term of a recent study on the sieve size effect using 20-390 $\mathrm{mm} \mathrm{Co} / \mathrm{Al}_{2} \mathrm{O}_{3}$ catalyst particles [49]. Thus, the mass transfer effect is unlikely the main cause while the deactivation should be primarily responsible for the different TOF values obtained in these studies.

Further analysis of the data of Ma et al. [48] indicates that after 120-200 h of testing, the Co TOF value based on the initial Co dispersion was decreased by $34-52 \%$ and the higher loss percentage was observed on the smaller Co particles. Assuming that the intrinsic activity of Co sites at a given set of conditions was unchanged, the loss in $34-52 \%$ activity might indicate a loss in the same amount of Co active sites, or even loss in more amounts of cobalt active sites i.e., $50-90 \%$ in other studies [41,44,47]. These data suggest that the majority of cobalt active sites did not participate the reaction in the lab testing or in the commercial practice [50] due to site blocking, or deactivation. Therefore, design of new generation of cobalt FTS catalyst by preserving as much as Co active sites during FTS reaction and maximizing cobalt particles' activity is an urgent and important task, which could dramatically improve product yields and reduce capital cost in FTS.

\subsubsection{Examples of Iron Catalyst}

The iron particle size effects on FTS reaction were studied by many researchers as well, but the conclusion is still debatable. Earlier studies on the topic were conducted on 2.5-6.0\%Fe/Carbon (C) catalysts by Vaccine group [42], and on 1-10\%Fe on $\mathrm{C}$ or $/ \mathrm{Al}_{2} \mathrm{O}_{3}$ catalysts by Bartholomew group [43]. Both groups reported consistently that smaller Fe particles displayed lower activity after $\mathrm{H}_{2}$ pretreatment at $350{ }^{\circ} \mathrm{C}$, for example, the TOF for $\mathrm{CO}$ hydrogenation at $220^{\circ} \mathrm{C}, 0.1 \mathrm{MPa}$ and $\mathrm{H}_{2} / \mathrm{CO}=2.0$ increased from 0.86 to $4.4 \times 10^{-3} \mathrm{~s}^{-1}$ in a study by Vannice et al. [42] and 0.69 to $18 \times 10^{-3} \mathrm{~s}^{-1}$ in a study by Bartholomew et al. [43] with increasing Fe particle size from 0.6 to $9 \mathrm{~nm}$. These authors did not provide $\mathrm{CH}_{4}$ selectivity data, but an estimation based on the available $\mathrm{CH}_{4}$ and $\mathrm{CO}$ rates suggested lower $\mathrm{CH}_{4}$ selectivity on smaller iron carbides; furthermore, smaller Fe carbides were reported to have lower activation energy $(84-95 \mathrm{~kJ} / \mathrm{mol}$ or $64-105 \mathrm{~kJ} / \mathrm{mol})$. These results are presumably due to the difference in electronic density on the small and large particles, different Fe-C interaction, and/or a decrease in the corner and edge sites on large crystallites that were responsible for the increases in both turnover frequency and 
activation energy with increasing crystallite size. Small Fe particles i.e., 1-2 nm led to high deactivation rate $[42,43]$.

Recently, a progress on the study on Fe particle size effect was made by several research groups [51-53]. van Steen et al. [51] and Park et al. [52] explored the effects of Fe particle size in the ranges 3.0-19.2 nm over $2.8-4.7 \% \mathrm{Fe} / \mathrm{C}, 4.6-5.6 \% \mathrm{Fe} / \mathrm{g}-\mathrm{Al}_{2} \mathrm{O}_{3}$ and 2-12 nm over $5 \% \mathrm{Fe} / \mathrm{Al}_{2} \mathrm{O}_{3}$ catalysts, on FTS performance, respectively. After $\mathrm{H}_{2}$ reduction at $350{ }^{\circ} \mathrm{C}$, lower initial TOF on smaller Fe particles (3-10 $\mathrm{nm}$ by Steen, 2.0-6.2 $\mathrm{nm}$ by Park) was noticed, then it remained nearly constant up to the particle size of $19.2 \mathrm{~nm}$ or $12 \mathrm{~nm}$. For example, the stable TOF values for the $\mathrm{Fe} / \mathrm{Al}_{2} \mathrm{O}_{3}$ and $\mathrm{Fe} / \mathrm{C}$ catalysts with larger Fe particles in van Steen study under $270{ }^{\circ} \mathrm{C}, 3.0 \mathrm{MPa}, \mathrm{H}_{2} / \mathrm{CO}=2.0,7.2$ or $18 \mathrm{NL} / \mathrm{g}$-cat $/ \mathrm{h}(40$ and $8 \%$ $\mathrm{CO}$ conversion) were 3.1 and $6.0 \mathrm{mmol} / \mathrm{m}^{2}-\mathrm{Fe} / \mathrm{s}$, respectively (Figure $5 \mathrm{a}$ ), and $0.187 \mathrm{~s}^{-1}$ in Park study under $300{ }^{\circ} \mathrm{C}, 1 \mathrm{MPa}, 3.6 \mathrm{~L} /$ gcat $/ \mathrm{h}$, and $\mathrm{H}_{2} / \mathrm{CO}=2$ (Figure $5 \mathrm{~b}$ ). Thus, part of the van Steen and Park results in the small Fe particle size region are consistent with the previous studies of Vannice et al. [42] and Bartholomew et al. [43], and a most recent study by $\mathrm{Gu}$ et al. [72], which reported an increase in Fe TOF with increasing iron particle size in the $2.5-12 \mathrm{~nm}$ range under $350{ }^{\circ} \mathrm{C}, 0.1-10 \mathrm{MPa}$, and $\mathrm{H}_{2} / \mathrm{CO}=1.0$ and $60 \% \mathrm{CO}$ conversion. However, there is a difference in the Fe particle size threshold (10 vs. $6.2 \mathrm{~nm})$, at which the TOF starts to be stable, in the studies. The difference could arise from the support effects and/or errors in the characterization and activity measurements.
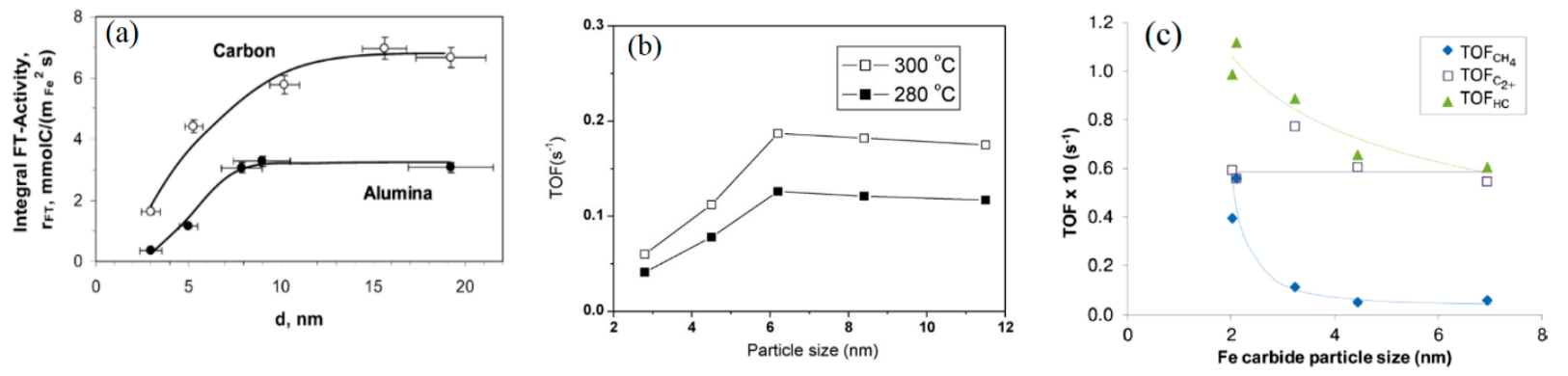

Figure 5. (a) Initial integral activity per unit surface area over carbon supported iron-based catalysts at $270{ }^{\circ} \mathrm{C}$ and $3.0 \mathrm{MPa}$ $\mathrm{H}_{2} / \mathrm{CO}=2,7.2 \mathrm{NL} / \mathrm{g}$-cat $/ \mathrm{h}$, and $\mathrm{X}_{\mathrm{CO}}=20-75 \%$; alumina-supported catalysts: $18 \mathrm{NL} / \mathrm{g}$-cat $/ \mathrm{h}$, and, $\mathrm{X}_{\mathrm{CO}}=6-15 \%$ (from [51]), (b) The influence of iron particle size on the TOF at 280 and $300{ }^{\circ} \mathrm{C}, 1.0 \mathrm{MPa}, 7.2 \mathrm{NL} / \mathrm{g}$-cat/h, and $\mathrm{H}_{2} / \mathrm{CO}=2.0$ (reproduced with permission from [52] Copyright 2010, Elsevier), (c) TOF as a function of iron carbide size $340{ }^{\circ} \mathrm{C}, 2.0 \mathrm{MPa}, \mathrm{H}_{2} / \mathrm{CO}=1$, (reproduced with permission from [53] Copyright 2012, ACS).

Interestingly, de Jong group [53,73] studied the conversion of syngas to light olefins (FTO) over 1, 2, 5, 10 and 20\% Fe supported on carbon nano fiber (CNT) with and without $\mathrm{Na}$ and $\mathrm{S}$ promoters in a micro fixed bed reactor. A different Fe particle size effect from that in the van Steen et al. [51] and Park et al. studies [52] was reported in the Fe size range of 2-17 $\mathrm{nm}$ [53] or 3-9 nm [73]. After the iron catalysts were reduced in $\mathrm{H}_{2}$ at $350{ }^{\circ} \mathrm{C}$ for $2 \mathrm{~h}$, it led to a decreased trend of $\mathrm{CO}$ to hydrocarbons TOF from 0.1 to $0.06 \mathrm{~s}^{-1}$ with increasing $\mathrm{Fe}_{\mathrm{x}} \mathrm{C}$ size from 2 to $7 \mathrm{~nm}$ at $340{ }^{\circ} \mathrm{C}, 2 \mathrm{MPa}, \mathrm{H}_{2} / \mathrm{CO}=1$, and $5.45 \mathrm{NL} / \mathrm{g}$-cat/h [53] (Figure 5c). At a low pressure $0.1 \mathrm{MPa}$ and $350{ }^{\circ} \mathrm{C}$, the same trend was also obtained, however, the $\mathrm{CO}$ conversion remained nearly unchanged (9-11\%) for the unpromoted 1, 2, 5, 10 and $20 \% \mathrm{Fe} / \mathrm{CNT}$ catalysts at a constant flow rate $(6 \mathrm{~mL} / \mathrm{min}$ vs. $0.02 \mathrm{~g}$ cat $)$. With the absence of the Fe reduction degree data, it is estimated from the available rates and Fe dispersion data that the extent of Fe reduction is relative constant despite significant change in Fe loading from 1 to $20 \%$. These results are unusual that cannot be explained by the common knowledge of metal loading effect. It is likely that many iron active sites on high Fe loading catalysts did not participate in reaction in the low pressure. The authors also reported higher $\mathrm{CH}_{4}$ selectivity on smaller Fe particles, which is consistent with the study of Park et al. [52], but against the results of Vannice et al. [42] and Bartholomew et al. [43]. The reasons for the opposite Fe particle size effects obtained by Torres et al. [53] and 
Gu et al. [73] is not known. Additional efforts are needed to clarify the issue of iron particle size effect.

Further comparison of various studies on Fe catalysts suggests that the TOF values of the Fe particles over $7 \mathrm{~nm}$ reported by Park et al. [52], Chang et al. [14] and Ma et al. [5] under $260-300{ }^{\circ} \mathrm{C}, 1-3 \mathrm{MPa}, \mathrm{H}_{2} / \mathrm{CO}=1-2$ and $20-50 \% \mathrm{CO}$ conversion are essentially consistent, and they fall into the range $0.046-0.20 \mathrm{~s}^{-1}$. These high TOF values should be close to the Fe intrinsic activity due to the consistency of the results and the ignored mass transfer effect by using fine particles in these studies. Thus, the Fe TOF values reported can serve as reference for the design of highly active Fe catalysts. Recently, Keyvanloo et al. [54] prepared highly active $40 \% \mathrm{Fe} / \mathrm{AlSi}$ and $40 \% \mathrm{Fe} / \mathrm{AIG}$ (including $5 \% \mathrm{La}$ ) supported catalysts. The activity of the supported Fe catalysts with $8 \mathrm{~nm} \mathrm{Fe} \times \mathrm{C}$ under $260^{\circ} \mathrm{C}, 2.0 \mathrm{MPa}, \mathrm{H}_{2} / \mathrm{CO}=1$ was estimated to be $0.045 \mathrm{~s}^{-1}$, which is consistent with the reported TOF value. However, the CO TOF for the Fe catalyst with $7 \mathrm{~nm}$ Fe particle size reported by Torres et al. [53] was about 10 times lower, $0.017 \mathrm{~s}^{-1}$ at $300{ }^{\circ} \mathrm{C}$ (corrected from $0.06 \mathrm{~s}^{-1}$ at $340{ }^{\circ} \mathrm{C}$ and assuming $\mathrm{E}_{\mathrm{a}}=90 \mathrm{~kJ} / \mathrm{mol}$ ), while the activity on the $\mathrm{Fe} / \mathrm{C}$ and $\mathrm{Fe} / \mathrm{Al}_{2} \mathrm{O}_{3}$ catalysts reported by Barkhuizen et al. [51] was significantly beyond the range (80-200 times higher), $12-51 \mathrm{~s}^{-1}$ at $260-300{ }^{\circ} \mathrm{C}$ (estimated from the reported $3-6 \mathrm{mmol} / \mathrm{m}^{2} \mathrm{Fe} / \mathrm{s}$ at $270{ }^{\circ} \mathrm{C}$ and assuming $\mathrm{Fe}$ density 20.4 atoms $/ \mathrm{nm}^{2}$ ). The primary causes for the large difference in the TOF in the studies $[51,53]$ are not known.

\subsubsection{Examples of Ruthenium Catalyst}

The effects of Ru particle size on FTS were explored by many researchers and the results are more similar to that of the Co particle size effect as discussed above, but some differences from study to study still exist. Systematic early studies on the effect of Ru particle size on FTS performance were reported by Kellner et al. [55] and Iglesia [8], which suggested structure insensitive of the FTS reaction, i.e., both studies indicated Ru time yield was independent of support type $\left(\mathrm{Al}_{2} \mathrm{O}_{3}, \mathrm{SiO}_{2}\right.$, and $\left.\mathrm{TiO}_{2}\right)$ and increased linearly with increasing $\mathrm{Ru}$ dispersion. The $\mathrm{Ru}$ time yield changed from 0.0012 to $0.0065 \mathrm{~s}^{-1}$ at $203{ }^{\circ} \mathrm{C}$, $0.56 \mathrm{MPa}, \mathrm{H}_{2} / \mathrm{CO}=2.1$ and $45-60 \% \mathrm{CO}$ conversion when $\mathrm{Ru}$ dispersion increased from 8.5 to $46 \%$ (Figure 6a) [8]. Based on the relationship between the Ru particles size and dispersion $\left(\mathrm{d}_{\mathrm{Ru}}=132 / \mathrm{D}\right), 8.5$ to $46 \% \mathrm{Ru}$ dispersion corresponds to the Ru particle size of 3.0 to $15.5 \mathrm{~nm}$, in which the slope yields a constant Ru TOF of $1.41 \times 10^{-2} \mathrm{~s}^{-1}$. In recent years, there has been an increasing interest in exploring the Ru particle size effect, probably inspired by the early Ru works and/or by the recent studies of Co particle size effect. A similar trend (constant TOF) at large Ru particles of $10-23 \mathrm{~nm}\left(0.108 \mathrm{~s}^{-1}\right.$ at $250{ }^{\circ} \mathrm{C}, 0.2 \mathrm{MPa}$, and $\left.\mathrm{H}_{2} / \mathrm{CO}=10\right)$ using $\mathrm{Ru} / \mathrm{Al}_{2} \mathrm{O}_{3}$ catalyst or at $7-12 \mathrm{~nm}\left(0.105 \mathrm{~s}^{-1}\right.$ at $240{ }^{\circ} \mathrm{C}, 1.5 \mathrm{MPa}$, and $\mathrm{H}_{2} / \mathrm{CO}=2$ ) using 3.6-17.3\%.Ru/C catalyst was reported by Carballo et al. [7] and Eslava et al. [56], respectively; at Ru sizes smaller than 7 or $10 \mathrm{~nm}$, Ru TOF was found to increase with increasing Ru size (Figure 6b). Apparently, the results of Carballo and Eslava about the Ru particle size effect were quite similar to that of the Co particle size effect (Co size threshold: 8-10 $\mathrm{nm}$ ) [41,44-47,64] and some of the Fe particle size effect studies (Fe size threshold: 7-10 nm) [51,52]. The smaller nano Ru particles showed lower activity, which was explained by strong adsorption of surface species and blocking of active sites. Later, Carballo et al. [57] reported a different Ru particle size effect on the initial activity in the $\mathrm{Ru}$ particle size range 4 to $71 \mathrm{~nm}$ over $3 \% \mathrm{Ru} / \mathrm{Al}_{2} \mathrm{O}_{3}$ (Figure $6 \mathrm{c}$ ). The initial TOF values increased with Ru particle size, but the incremental pace became slower at the $\mathrm{Ru}$ size greater than $10 \mathrm{~nm}$. This unique trend of the initial activity was presumably due to loss in the step-edges sites on the large Ru particles i.e., $>10 \mathrm{~nm}$, for CO dissociation, while the terraces sites might remain unchanged. The small Ru particles likely favored the production of $\mathrm{CH}_{4}$ and lowered $\mathrm{C}_{5+}$ hydrocarbons. 

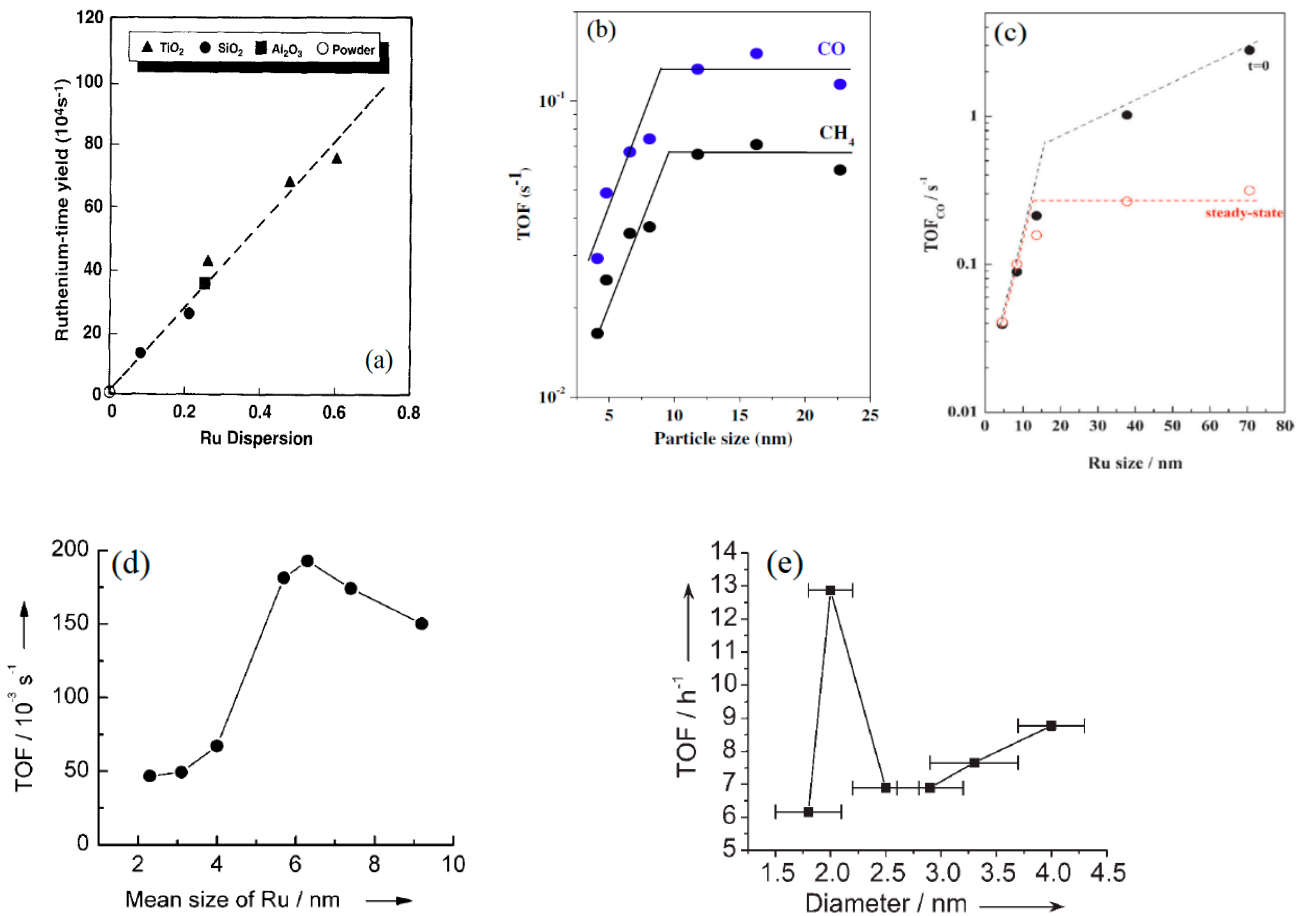

Figure 6. (a) Effects of ruthenium dispersion on Fischer-Tropsch synthesis rates at $203{ }^{\circ} \mathrm{C}, \mathrm{H}_{2} / \mathrm{CO}=2.1,0.56 \mathrm{MPa}, 45-60 \%$ CO conversion (reproduced with permission from [8] Copyright 1992, Academic Press. Inc.), (b) Effects of Ru particle size on turnover frequencies for $\mathrm{CO}$ consumption and $\mathrm{CH}_{4}$ formation rates at $250{ }^{\circ} \mathrm{C} ; 0.2 \mathrm{MPa}, \mathrm{H}_{2} / \mathrm{CO}=1$ (reproduced with permission from [7] Copyright 2011, Elsevier), (c) Evolution of TOF CO with Ru particle size at the beginning of the reaction, $\mathrm{t}=0$, and after $20 \mathrm{~h}$ on stream, steady-state regime (reproduced with permission from [57] Copyright 2014, Wiley-VCH Verlag GmbH \& Co.), (d) Dependence of TOF on the mean size of Ru particles at $260{ }^{\circ} \mathrm{C} ; 2 \mathrm{MPa}, \mathrm{H}_{2} / \mathrm{CO}=1$ (reproduced with permission from [58] Copyright 2009, Wiley-VCH Verlag GmbH \& Co.), (e) TOF as a function of diameter of the Ru nanoparticles at $150{ }^{\circ} \mathrm{C} ; 3 \mathrm{MPa}, \mathrm{H}_{2} / \mathrm{CO}=2$ (reproduced with permission from [59] Copyright 2008, Wiley-VCH Verlag $\mathrm{GmbH} \& \mathrm{Co}$.$) .$

Recently, Wang group [58,75] studied the Ru size effects in the range of 2.4-10 nm with $3 \% \mathrm{Ru}$ on various supported catalysts $\left(\mathrm{SiO}_{2}, \mathrm{Al}_{2} \mathrm{O}_{3}, \mathrm{TiO}_{2}, \mathrm{MaO}, \mathrm{ZrO}_{2}, \mathrm{HY}, \mathrm{NaY}, \mathrm{H}-\right.$ beat, CNT, $\mathrm{AC}$, graphite) at a high temperature $260{ }^{\circ} \mathrm{C}$, and $2.0 \mathrm{MPa} \mathrm{H}_{2} / \mathrm{CO}=1.0,2.4 \mathrm{NL} / \mathrm{g}$-cat $/ \mathrm{h}$. Such Ru size effect namely a constant TOF beyond $7 \mathrm{~nm}$ Ru size as discussed above was not observed, instead a peak TOF $\left(0.193 \mathrm{~s}^{-1}\right)$ (Figure $6 \mathrm{~d}$ ) and a peak selectivity to $C_{10}-C_{20}$ $(\sim 62 \%)$ were reported at the Ru size of $6.3 \mathrm{~nm}$ [58]. The TOF was decreased in the large $\mathrm{Ru}$ size range between 7 and $10 \mathrm{~nm}$, which is different from the studies of Carballo [7], Iglesia [8] and Kellner [55]. The catalyst deactivation and/or support effect could be responsible for the varied results. Xiao et al. [59] recently studied the effects of Ru size on FTS activity in aqueous phase. Authors obtained a narrow Ru particle size $1.8-4 \mathrm{~nm}$ by changing Ru loading from 0.5 to $5 \%$ on PVP. The authors observed a maximum activity of $6.9 \mathrm{~mol} / \mathrm{mol} \mathrm{Ru} / \mathrm{h}$ at a low temperature $150{ }^{\circ} \mathrm{C}$ and $3 \mathrm{MPa}, \mathrm{H}_{2} / \mathrm{CO}=2.0$ in a batch reactor, which was 6-35 times higher than that of other $\mathrm{Ru} / \mathrm{SiO}_{2}$ and $\mathrm{Ru} / \mathrm{Al}_{2} \mathrm{O}_{3}$ catalysts. The results suggest a strong support effect on the $\mathrm{Ru} / \mathrm{SiO}_{2}$ and $\mathrm{Ru} / \mathrm{Al}_{2} \mathrm{O}_{3}$ catalysts. More interestingly, an unprecedented peak TOF value of $12.9 \mathrm{~h}^{-1}$ at the Ru size of $2.0 \mathrm{~nm}$ was reported, after that Ru size point, the TOF increased gradually with increasing Ru size from 2.5 to $4.0 \mathrm{~nm}$ (Figure 6e). This result is rather unique, that no atomic-level explanation is currently available to rationalize the variation.

The above studies suggest more complicated Ru particle size effects despite many of the studies tend to show similar Ru size effect to the Co catalyst (two size regions' effects). Additional efforts are needed to elucidate the unusual trends on the Ru catalyst. On the other hand, it is difficult to compare the Ru activity per active site (TOF) in different studies because temperatures used were varied. Corrections in the $\mathrm{Ru}$ TOF obtained at different temperatures to the values at a given temperature i.e., $220{ }^{\circ} \mathrm{C}$, assuming the $\mathrm{Ru}$ 
activation energy for $\mathrm{CO}$ hydrogenation is $65 \mathrm{~kJ} / \mathrm{mol}$, make it possible to understand the catalyst's working efficiency. It is found that the estimated $\mathrm{Ru}$ TOF values in the $\mathrm{Ru}$ size 7-40 nm under $220{ }^{\circ} \mathrm{C}, 0.56-4 \mathrm{MPa}, \mathrm{H}_{2} / \mathrm{CO}=2.0$ in most Ru studies [7,8,56-59], fall into $0.025-0.075 \mathrm{~s}^{-1}$. However, the results in several other studies over Ru catalysts are different. Based on the initial $\mathrm{Ru}$ activity of a $3 \% \mathrm{Ru} / \gamma-\mathrm{Al}_{2} \mathrm{O}_{3}$ with $\mathrm{Ru}$ size of $70 \mathrm{~nm}$ in the study of Carballo et al. [57], and a study with Pt promoted $\mathrm{Ru}$ shell catalyst $(\mathrm{Pt} / \mathrm{Ru}=1 / 9)$ in aqueous FTS reaction by Li et al. [30], the estimated $\mathrm{Ru}$ TOF at $6.8 \mathrm{~nm}$ at $220^{\circ} \mathrm{C}$ and 2-4 MPa was about one order of magnitude higher, reaching $0.4-0.44 \mathrm{~s}^{-1}$. This Ru TOF value is slightly higher than that in a recent study with an active $2.2 \% \mathrm{Ru} / \mathrm{TiO}_{2}$ catalyst having similar Ru particle size [60], which gave Ru TOF of $0.3 \mathrm{~s}^{-1}$ at $220{ }^{\circ} \mathrm{C}$ and $2 \mathrm{MPa}$. Comparing these high $\mathrm{Ru}$ TOF values, it is concluded that the intrinsic activity of the $\mathrm{Ru}$ catalyst at $220^{\circ} \mathrm{C}$ should fall into $0.4-0.44 \mathrm{~s}^{-1}$. The low activity of the Ru catalysts suggests that most Ru research catalysts were far from the high efficiency, and majority of Ru active sites in catalysts had not participated in the FT reaction. In terms of the above data analysis, the design of new Ru catalyst should aim at taking advantage of every Ru sites for the FTS reaction, so that potential productivity of the Ru catalyst can be reached. The study further suggests that the intrinsic activity of $\mathrm{Ru}$ catalyst is about 3 times higher than that of $\mathrm{Co}$ catalyst (TOF: 0.4 vs. $0.1 \mathrm{~s}^{-1}$ at $220^{\circ} \mathrm{C}$ ).

\section{Conclusions}

Fossil fuel energy will continue to be the dominant energy resource in the world over the next several decades; thus, catalytic conversion of carbonaceous containing materials including coal, natural gas, biomass, organic wastes, biogas and $\mathrm{CO}_{2}$ to liquid and hydrogen fuels (XTF) and chemicals (XTC) can serve as a sustainable, efficient and clean approach to partly supply nations' energy need and reduce $\mathrm{CO}_{2}$ emission. FTS is one of the important XTF/XTC processes that play a key role in cleaner utilization of the carbon resources for fuels and chemicals production.

The recent studies on the effects of FTS catalysts' structure (crystal and size) on FTS performance is comparatively reviewed and summarized. The crystal structure of the catalysts plays decisive roles on FTS performance, but the effects are so complicated. Not only the crystal type but also morphology including shape, facet, edge and corner, affect catalyst activity and selectivity. Due to differing carbon chemical potential, one active iron carbide site that is good for high activity may not favor the formation of the desired products. For example, $\mathrm{Fe}_{7} \mathrm{C}_{3}$ is the most active, while $\varepsilon-\mathrm{Fe}_{2} \mathrm{C}$ gives lower methane selectivity. In the case of $\mathrm{Co}$ and Ru catalysts, close packed metal (hcp) and face centered cubic (fcc) have been evidenced, but two phases in the two types of catalysts show opposite activity trends at the same particle size, i.e., Co: hcp > fcc, Ru: fcc $>$ hcp, which reflects complex effects of morphology and facet on the Co and Ru catalysts. Multiple reaction pathways could occur on catalyst step-edge or terraces sites due to different $\mathrm{CO} / \mathrm{H}$ dissociation energy on the sites. The phase transformation for all three types of FTS catalysts during the reaction $\left(\mathrm{Fe}_{\mathrm{x}} \mathrm{C} \rightleftharpoons \mathrm{Fe}_{\mathrm{y}} \mathrm{C} \rightleftharpoons \mathrm{Fe}_{3} \mathrm{O}_{4}, \mathrm{hcp} \rightleftharpoons \mathrm{fcc}\right.$ ) make the FTS catalysis even more complicated. Therefore, further improving stability, activity and selectivity of FTS catalyst is challenging and should consider the environment that the catalyst is exposed to. It is possible to successfully tune catalyst structure toward the target products with the aid of the advanced technique of molecular level catalyst design plus massive experimental trials.

The recent studies related to particle size effects were thoroughly compared and discussed in this review. Based on the extensive studies on the topic, it was concluded that there are two metal size regions in which the FTS activity (TOF) of Co, Fe and Ru catalysts changed with particle size in a different manner. In the small particle size region, for example, below $8 \mathrm{~nm}$ for cobalt particles or $7 \mathrm{~nm}$ for iron and ruthenium particles, the activity of the catalysts started to increase dramatically, whereas in the big particle size greater than the threshold, the activity was independent of metal particle size. The threshold of the particle size reported in some studies was extended to $10 \mathrm{~nm}$. The reasons 
why small metal particles offered low activity has been explained by site blocking at particles' edge or corner, and/or oxidation of small nanoparticles. However, inconsistent results in the small particle size region for the iron and ruthenium catalysts present in some studies i.e., opposite activity trend on small iron particles and peak TOF value at $2 \mathrm{~nm}$ ruthenium particle, were observed. Thus, the effects of particle size on the FTS activity of iron and ruthenium catalysts have not reached a consensus. Additional studies are needed to clarify the discrepancy.

The activity of the $\mathrm{Co}$, Fe and Ru catalysts were studied by analyzing activity data of many researchers. Based on the literature studies, the intrinsic activity of $\mathrm{Co}$ and $\mathrm{Ru}$ particles of 7-70 nm at $220^{\circ} \mathrm{C}$ were estimated to be $0.1 \mathrm{~s}^{-1}$ and $0.4-0.44 \mathrm{~s}^{-1}$, respectively, while that of the Fe catalysts of $10 \mathrm{~nm}$ at $260-300{ }^{\circ} \mathrm{C}$ was $0.046-0.20 \mathrm{~s}^{-1}$. However, most of the research catalysts or some industrial catalysts only contributed $10-50 \%$ of potential activity due to the support, electronic or deactivation effects. Therefore, further improvement of activity of the FTS catalysts to a higher level is an important and urgent task in future study.

Author Contributions: Conceptualization, methodology, validation, data analysis, original draft preparation and editing: W.M.; Conceptualization, review and editing, validation, A.K.D. All authors have read and agreed to the published version of the manuscript.

Funding: This research received no external funding.

Acknowledgments: The authors would like to acknowledge the support of the Commonwealth of Kentucky and Canada Research Chair Program. This paper is dedicated to the late Burtron H. Davis, who inspires us from heaven.

Conflicts of Interest: The authors declare no conflict of interest.

\section{References}

1. U.S. Energy Information Administration's International Energy Outlook 2020 (IEO2020). Available online: https: / /www.eia.gov / outlooks/ieo/pdf/ieo2020.pdf (accessed on 30 October 2020).

2. Dry, M. The Fischer-Tropsch Process: 1950-2000; Elsevier: Amsterdam, The Netherlands, 2002; Volume 71, pp. 227-241. [CrossRef]

3. Xiang, H.W.; Yang, Y.; Li, Y.W. Indirect coal-to-liquids technology from fundamental research to commercialization. Sci. Sin. Chim. 2014, 14, 1876-1892. [CrossRef]

4. Khodakov, A.Y.; Chu, W.; Fongarland, P. Advances in the Development of Novel Cobalt Fischer-Tropsch Catalysts for Synthesis of Long-Chain Hydrocarbons and Clean Fuels. Chem. Rev. 2007, 107, 1692-1744. [CrossRef] [PubMed]

5. Ma, W.; Jacobs, G.; Spark, D.E.; Todic, B.; Bukur, D.B. Quantitative comparison of iron and cobalt based catalysts for the Fischer-Tropsch synthesis under clean and poisoning conditions. Catal. Today 2020, 343, 125-136. [CrossRef]

6. Carballo, J.M.G.; Finocchio, E.; García, S.; Rojas, S.; Ojeda, M.; Busca, G.; Fierro, J.L.G. Support effects on the structure and performance of ruthenium catalysts for the Fischer-Tropsch synthesis. Catal. Sci. Technol. 2011, 1, 1013-1023. [CrossRef]

7. Carballo, J.M.G.; Yang, J.; Holmen, A.; Garcia-Rodriguez, S.; Rojas, S.; Ojeda, M.; Fierro, J.L.G. Catalytic effects of ruthenium particle size on the Fischer-Tropsch Synthesis. J. Catal. 2011, 284, 102-108. [CrossRef]

8. Iglesia, E.; Soled, R.S.L.; Fiato, A. Fischer-Tropsch synthesis on cobalt and ruthenium. Metal dispersion and support effects on reaction rate and selectivity. J. Catal. 1992, 137, 212-224. [CrossRef]

9. Yang, J.; Shafer, W.D.; Pendyala, V.R.R.; Jacobs, G.; Ma, W.; Chen, D.; Holmen, A.; Davis, B.H. Fischer-Tropsch Synthesis: Deuterium Kinetic Isotopic Effect for a $2.5 \% \mathrm{Ru} / \mathrm{NaY}$ Catalyst. Top. Catal. 2014, 57, 508-517. [CrossRef]

10. Ma, W.P.; Shafer, W.D.; Martinelli, M.; Sparks, D.E.; Davis, B.H. Fischer-Tropsch Synthesis: Using deuterium tracer coupled with kinetic approach to study the kinetic isotopic effects of iron, cobalt and ruthenium catalysts. Catal. Today 2020, 343, 137-145. [CrossRef]

11. Dry, M.E. Fischer-Tropsch Synthesis. In Catalysis—Science and Technology; Anderson, J.R., Boudart, M., Eds.; Springer: New York, NY, USA, 1981; Chapter 4; Volume 1, p. 196.

12. De Smit, E.; Cinquini, F.; Beale, A.M.; Safonova, O.V.; van Beek, W.; Sautet, P.; Weckhuysen, B.M. Stability and Reactivity of $\epsilon-\chi-\theta$ Iron Carbide Catalyst Phases in Fischer-Tropsch Synthesis: Controlling $\mu$ C. J. Am. Chem. Soc. 2010, 132, 14928-14941. [CrossRef]

13. Davis, B.H. Fischer-Tropsch Synthesis: Reaction mechanisms for iron catalysts. Catal. Today 2009, 141, 25-33. [CrossRef]

14. Chang, Q.; Zhang, C.; Liu, C.; Wei, Y.; Cheruvathur, A.V.; Dugulan, A.I.; Niemantsverdriet, J.W.; Liu, X.; He, Y.; Qing, M.; et al. Relationship between Iron Carbide Phases $\left(\varepsilon-\mathrm{Fe}_{2} \mathrm{C}, \mathrm{Fe}_{7} \mathrm{C}_{3}\right.$, and $\left.\chi-\mathrm{Fe}_{5} \mathrm{C}_{2}\right)$ and Catalytic Performances of Fe/SiO2 Fischer-Tropsch Catalysts. ACS Catal. 2018, 8, 3304-3316. [CrossRef] 
15. Lu, F.X.; Chen, X.; Lei, Z.G.; Wen, L.X.; Zhang, Y. Revealing the activity of different iron carbides for Fischer-Tropsch synthesis. Appl. Catal. B Environ. 2021, 281, 119521. [CrossRef]

16. Huo, C.F.; Li, Y.W.; Wang, J.; Jiao, H. Insight into CH4 Formation in Iron-Catalyzed Fischer-Tropsch Synthesis. J. Am. Chem. Soc. 2009, 131, 14713-14721. [CrossRef]

17. Van Santen, R.A.; Ghouri, M.M.; Shetty, S.; Hensen, E.M.H. Structure sensitivity of the Fischer-Tropsch reaction: Molecular kinetics simulations. Catal. Sci. Technol. 2011, 1, 891-911. [CrossRef]

18. Ralston, W.T.; Melaet, G.; Saephan, T.; Somorjai, G.A. Evidence of Structure Sensitivity in the Fischer-Tropsch Reaction on Model Cobalt Nanoparticles by Time-Resolved Chemical Transient. Angew. Chem. Int. Ed. 2017, 56, 7415-7419. [CrossRef]

19. Ducreux, O.; Rebours, B.; Lynch, J.; Roy-Auberger, M.; Bazin, D. Microstructure of Supported cobalt Fischer-Tropsch catalysts. Oil Gas Sci. Tech. 2009, 64, 49-62. [CrossRef]

20. Khodakov, A.Y. Fischer-Tropsch synthesis: Relations between structure of cobalt catalysts and their catalytic performance. Catal. Today 2009, 144, 251-257. [CrossRef]

21. Sadeqzadeh, M.; Karaca, H.; Safonova, O.V.; Fongarland, P.; Chambrey, S.; Roussel, P.; Griboval-Constant, A.; Lacroix, M.; Curulla-Ferre, D.; Luck, F.; et al. Identification of the active species in the working alumina-supported cobalt catalyst under various conditions of Fischer-Tropsch synthesis. Catal. Today 2011, 164, 62-67. [CrossRef]

22. Gnanamani, M.K.; Jacobs, G.; Shafer, W.D.; Davis, B.H. Fischer-Tropsch synthesis: Activity of metallic phases of cobalt supported on silica. Catal. Today 2013, 215, 13-17. [CrossRef]

23. Dinega, D.P.; Bawendi, M.G. A Solution-Phase Chemical Approach to a New Crystal Structure of Cobalt. Angew. Chem. Int. Ed. 1999, 38, 1788-1791. [CrossRef]

24. Enache, D.I.; Rebours, B.; Roy-Auberger, M.; Revel, R. In Situ XRD Study of the Influence of Thermal Treatment on the Characteristics and the Catalytic Properties of Cobalt-Based Fischer-Tropsch Catalysts. J. Catal. 2002, 205, 346-353. [CrossRef]

25. Liu, J.; Su, H.; Sun, D.; Zhang, B.; Li, W. Crystallographic dependence of CO activation on cobalt catalysts: HCP versus FCC. J. Am. Chem. Soc. 2013, 135, 16284-16287. [CrossRef]

26. Mohandas, J.C.; Gnanamani, M.K.; Jacobs, G.; Ma, W.P.; Ji, Y.; Khalid, S.; Davis, B.H. Fischer Tropsch Synthesis: Characterization and Reaction Testing of Cobalt Carbide. ACS Catal. 2011, 1, 1581-1588. [CrossRef]

27. Jalama, K.; Ma, W.P.; Jacob, G.; Sparks, D.; Qian, D.L.; Davis, B.H. Fischer-Tropsch synthesis over $\mathrm{Pt}_{\mathrm{t}} \mathrm{Co} / \mathrm{Al}_{2} \mathrm{O}_{3}$ catalyst: Improvement in catalyst stability by activation with diluted CO. Appl. Catal. 2020, 602, 117645. [CrossRef]

28. Jiao, G.P.; Ding, Y.J.; Zhu, H.J.; Li, X.; Li, J.; Lin, R.; Dong, W.; Gong, L.; Pei, Y.; Lu, Y. Effect of $\mathrm{La}_{2} \mathrm{O}_{3}$ doping on syntheses of $\mathrm{C}_{1}-\mathrm{C}_{18}$ mixed linear $\alpha$-alcohols from syngas over the Co/AC catalysts. Appl. Catal. 2009, 364, 137-142. [CrossRef]

29. Pei, Y.P.; Ding, Y.J.; Zhu, H.J.; Du, H. One-step production of C1-C18 alcohols via Fischer-Tropsch reaction over activated carbon-supported cobalt catalysts: Promotional effect of modification by $\mathrm{SiO}_{2}$. Chin. J. Catal. 2015, 36, 355-361. [CrossRef]

30. Li, W.Z.; Liu, J.X.; Gu, J.; Zhou, W.; Yao, S.Y.; Si, R.; Guo, Y.; Su, H.Y.; Yan, C.H.; Li, W.X.; et al. Chemical Insights into the Design and Development of Face-Centered Cubic Ruthenium Catalysts for Fischer-Tropsch Synthesis. J. Am. Chem. Soc. 2017, 139, 2267-2276. [CrossRef]

31. Yang, Y.; Xiang, H.W.; Xu, Y.Y.; Bai, L.; Li, Y.W. Effect of potassium promoter on precipitated iron-manganese catalyst for Fischer-Tropsch synthesis. Appl. Catal. 2004, 266, 181-194. [CrossRef]

32. Tian, Z.P.; Wang, C.H.; Yue, J.; Zhang, X.H.; Ma, L.L. Effect of a potassium promoter on the Fischer-Tropsch synthesis of light olefins over iron carbide catalysts encapsulated in graphene-like carbon. Catal. Sci. Technol. 2019, 9, 2728-2741. [CrossRef]

33. Tao, Z.; Yang, Y.; Wan, H.; Li, Y.W. Effect of manganese on a potassium-promoted iron-based Fischer-Tropsch synthesis catalyst. Catal. Lett. 2007, 114, 161-168. [CrossRef]

34. Ribeiro, M.C.; Jacobs, G.; Pendyala, R.; Davis, B.H.; Cronauer, D.C.; Kropf, A.J.; Marshall, C.L. Fischer-Tropsch Synthesis: Influence of Mn on the Carburization Rates and Activities of Fe-Based Catalysts by TPR-EXAFS/XANES and Catalyst Testing. J. Phys. Chem. C 2011, 115, 4783-4792. [CrossRef]

35. Yang, Y.; Xiang, H.W.; Tian, L.; Wang, H.; Zhang, C.H.; Tao, Z.C.; Xu, Y.Y.; Zhong, B.; Li, Y.W. Structure and Fischer-Tropsch performance of iron-manganese catalyst incorporated with SiO2. Appl. Catal. A Gen. 2005, 284, 105-122. [CrossRef]

36. Nurunnabi, M.; Murata, K.; Okabe, K.; Inaba, M.; Takahara, I. Performance and characterization of Ru/Al2O3 and Ru/SiO2 catalysts modified with Mn for Fischer-Tropsch synthesis. Appl. Catal. 2008, 340, 203-211. [CrossRef]

37. Chen, Y.W.; Wang, H.T.; Goodwin, J.G.; Shiflett, W.K., Jr. Fischer-tropsch synthesis over zeolite-supported ruthenium catalysts derived from Ru3(CO)12. Appl. Catal. 1983, 8, 303-314. [CrossRef]

38. Boudart, M. Advances in Catalysis and Related Subjects; Eley, D.D., Ed.; Academic Press: New York, NY, USA, 1969; Volume 20, p. 85.

39. Li, J.L.; Coville, N.J. The effect of boron on the catalyst reducibility and activity of $\mathrm{Co} / \mathrm{TiO}_{2}$ Fischer-Tropsch catalysts. Appl. Catal. 1999, 181, 201-208. [CrossRef]

40. Iglesia, E.; Reyes, S.C.; Madon, R.J.; Soled, S.L. Selectivity Control and Catalyst Design in the Fischer-Tropsch Synthesis: Sites, Pellets, and Reactors. Adv. Catal. 1993, 39, 221-302. [CrossRef]

41. Iglesia, E. Design, synthesis, and use of cobalt-based Fischer-Tropsch synthesis catalysts. Appl. Catal. A Gen. 1997, 161, 59-78. [CrossRef]

42. Vannice, M.A. CO hydrogenation over well-dispersed carbon-supported iron catalysts. J. Catal. 1983, 75, 416-422.

43. Jones, V.K.; Neubauer, L.R.; Bartholomew, C.H. Effects of crystallite size and support on the CO hydrogenation activity/selectivlty properties of Fe/Carbon. J. Phys. Chem. 1986, 90, 4832-4839. [CrossRef] 
44. Bezemer, G.L.; Bitter, J.H.; Kuipers, P.C.E.; Oosterbeek, H.; Holewijn, J.E.; Xu, X.; Kapteijn, F.; van Dillen, A.J.; de Jong, K.P. Cobalt particle size effects in the Fischer-Tropsch reaction studied with carbon nanofiber supported catalysts. J. Am. Chem. Soc. 2006, 128, 3956-3964. [CrossRef] [PubMed]

45. Den Breejen, J.P.; Radstake, P.B.; Bezemer, G.L.; Bitter, J.H.; Frøseth, V.; Holmen, A.; de Jong, K.P. On the origin of the cobalt particle size effects in Fischer-Tropsch catalysis. J. Am. Chem. Soc. 2009, 131, 7197-7203. [CrossRef]

46. Borg, Ø.; Dietzel, P.D.; Spjelkavik, A.I.; Tveten, E.Z.; Walmsley, J.C.; Diplas, S.; Eri, S.; Holmen, A.; Rytter, E. Fischer-Tropsch synthesis: Cobalt particle size and support effects on intrinsic activity and product distribution. J. Catal. 2008, 259, 161-164. [CrossRef]

47. Prieto, G.; Martínez, A.; Concepción, P.; Moreno-Tost, R. Cobalt particle size effects in Fischer-Tropsch synthesis: Structural and in situ spectroscopic characterisation on reverse micelle-synthesised Co/ITQ-2 model catalysts. J. Catal. 2009, 266, 129-144. [CrossRef]

48. Ma, W.; Jacobs, G.; Keogh, R.A.; Bukur, D.B.; Davis, B.H. Fischer-Tropsch synthesis: Effect of Pd, Pt, Re, and Ru noble metal promoters on the activity and selectivity of a $25 \% \mathrm{Co} / \mathrm{Al}_{2} \mathrm{O}_{3}$ catalyst. Appl. Catal. 2012, 437, 1-9. [CrossRef]

49. Pendyala, V.R.R.; Jacobs, G.; Ma, W.; Klettlinger, J.L.S.; Yen, C.H.; Davis, B.H. Fischer-Tropsch synthesis: Effect of catalyst particle (sieve) size range on activity, selectivity, and aging of a Pt promoted $\mathrm{Co} / \mathrm{Al}_{2} \mathrm{O}_{3}$ catalyst. Chem. Eng. J. 2014, 249, 279-284. [CrossRef]

50. Saib, A.M.; Borgna, A.; de Loosdrecht, J.V.; van Berge, P.J.; Niemantsverdriet, J.W. XANES study of the susceptibility of nano-sized cobalt crystallites to oxidation during realistic Fischer-Tropsch synthesis. Appl. Catal. A 2006, 312, 12-19. [CrossRef]

51. Barkhuizen, D.; Mabaso, E.I.; Viljoen, E.; Welker, C.; Claeys, M.; van Steen, E.; Fletcher, J.C.Q. Experimental approaches to the preparation of supported metal nanoparticles. Pure Appl. Chem. 2006, 78, 1759-1769. [CrossRef]

52. Park, J.Y.; Lee, Y.J.; Khanna, P.K.; Jun, K.W.; Bae, J.W.; Kim, Y.H. Alumina-supported iron oxide nanoparticles as Fischer-Tropsch catalysts:Effect of particle size of iron oxide. J. Mol. Catal. A Chem. 2010, 323, 84. [CrossRef]

53. Torres, G.H.M.; Bitter, J.H.; Davidian, T.; Ruitenbeek, M.; Dugulan, A.I.; de Jong, K.P. Iron particle size effects for direct production of lower olefins from synthesis gas. J. Am. Chem. Soc. 2012, 134, 16207-16215. [CrossRef] [PubMed]

54. Keyvanloo, K.; Mardkhe, M.K.; Alam, T.M.; Bartholomew, C.H.; Woodfield, B.F.; Hecker, W.C. Supported Iron Fischer-Tropsch Catalyst: Superior Activity and Stability Using a Thermally Stable Silica-Doped Alumina Support. ACS Catal. 2014, 4, $1071-1077$. [CrossRef]

55. Kellner, C.S.; Bell, A.T. Effects of dispersion on the activity and selectivity of alumina-supported ruthenium catalysts for carbon monoxide hydrogenation. J. Catal. 1982, 75, 251-261. [CrossRef]

56. Eslava, J.L.; Sun, X.H.; Gascon, J.; Kapteijnb, F.; Ramos, I. Ruthenium particle size and cesium promotion effects in Fischer-Tropsch synthesis over high surface-area graphite supported catalysts. Catal. Sci. Technol. 2017, 7, 1235-1244. [CrossRef]

57. Carballo, J.M.G.; Alonso, F.J.P.; Ojeda, M.; Garcia-Garcia, F.J.; Fierro, J.L.G.; Rojas, S. Evidences of Two-Regimes in the Measurement of Ru Particle Size Effect for CO Dissociation during Fischer-Tropsch Synthesis. ChemCatChem 2014, 6, 2084-2094. [CrossRef]

58. Kang, J.; Zhang, S.; Zhang, Q.; Wang, Y. Ruthenium nanoparticles supported on carbon nanotubes as efficient catalysts for selective conversion of synthesis gas to diesel fuel. Angew. Chem. Int. Ed. 2009, 48, 2565-2568. [CrossRef] [PubMed]

59. Xiao, C.X.; Cai, Z.P.; Wang, T.; Kou, Y.; Yan, N. Aqueous-Phase Fischer-Tropsch Synthesis with a Ruthenium Nanocluster Catalyst. Angew. Chem. 2008, 120, 758-761. [CrossRef]

60. Zhang, Y.; Yang, X.; Yang, X.; Duan, H.; Qi, H.; Su, Y.; Liang, B.; Tao, H.; Liu, B.; Chen, D.; et al. Tuning reactivity of Fischer-Tropsch synthesis by regulating TiOx overlayer over $\mathrm{Ru} / \mathrm{TiO}_{2}$ nanocatalysts. Nat. Commun. 2020, 11, 3185. [CrossRef]

61. Fu, T.J.; Li, Z.H. Review of recent development in Co-based catalysts supported on carbon materials for Fischer-Tropsch synthesis. Chem. Eng. Sci. 2015, 135, 3-20. [CrossRef]

62. Gavrilović, L.; Save, J.; Blekkan, E.A. The effect of potassium on cobalt-based Fischer-Tropsch catalysts with different cobalt particle sizes. Catalysts 2019, 9, 351. [CrossRef]

63. Ghogia, A.C.; Nzihou, A.; Serp, P.; Soulantica, K.; Pham Minh, D. Cobalt catalysts on carbon-based materials for Fischer-Tropsch synthesis: A review. Appl. Catal. 2021, 609, 117906. [CrossRef]

64. Park, J.-Y.; Lee, Y.J.; Karandikar, P.R.; Jun, K.W.; Ha, K.S.; Park, H.G. Fischer-Tropsch catalysts deposited with size-controlled Co3O4 nanocrystals: Effect of Co particle size on catalytic activity and stability. Appl. Catal. 2012, 411, 15-23. [CrossRef]

65. Qi, Z.; Chen, L.; Zhang, S.; Su, J.; Somorjai, G.A. A mini review of cobalt-based nanocatalyst in Fischer-Tropsch synthesis. Appl. Catal. 2020, 602, 17701. [CrossRef]

66. Yang, J.; Frøseth, V.; Chen, D.; Holmen, A. Particle size effect for cobalt Fischer-Tropsch catalysts based on in situ CO chemisorption. Surf. Sci. 2016, 648, 67-73. [CrossRef]

67. Zhang, Q.; Deng, W.P.; Wang, Y. Recent advances in understanding the key catalyst factors for Fischer-Tropsch synthesis. J. Energy Chem. 2013, 22, 27-38. [CrossRef]

68. Jacobs, G.; Ma, W.P.; Gao, P.; Todic, B.; Bhatelia, T.; Bukur, D.B.; Khalid, S.; Davis, B.H. Fischer-Tropsch Synthesis: Differences Observed in Local Atomic Structure and Selectivity with Pd Compared to Typical Promoters (Pt, $\mathrm{Re}, \mathrm{Ru}$ ) of $\mathrm{Co} / \mathrm{Al}_{2} \mathrm{O}_{3} \mathrm{Catalysts}$. Top. Catal. 2012, 55, 811-817. [CrossRef]

69. Ghasvareh, P.; Smith, K.J. Effects of Co particle size on the stability of $\mathrm{Co} / \mathrm{Al}_{2} \mathrm{O}_{3}$ and $\mathrm{Re}-\mathrm{Co} / \mathrm{Al}_{2} \mathrm{O}_{3}$ catalysts in a slurry-phase Fischer-Tropsch reactor. Energy Fuels 2016, 30, 9721-9729. [CrossRef] 
70. Jacobs, G.; Ma, W.P.; Davis, B.H. Influence of Reduction Promoters on Stability of Cobalt/ $\gamma$-Alumina Fischer-Tropsch Synthesis Catalysts. Catalysts 2014, 4, 49-76. [CrossRef]

71. Liu, J.X.; Wang, P.; Xu, W.; Hensen, E.J. Particle size and crystal phase effects in Fischer-Tropsch catalysts. Engineering 2017, 3, 467-476. [CrossRef]

72. Gu, B.; Zhou, C.; He, S.; Moldovan, S.; Chernavskii, P.A.; Ordomsky, V.V.; Khodakov, A.Y. Size and promoter effects on iron nanoparticles confined in carbon nanotubes and their catalytic performance in light olefin synthesis from syngas. Catal. Today 2020, 357, 203-213. [CrossRef]

73. Xie, J.; Torres Galvis, H.M.; Koeken, A.C.J.; Kirilin, A.; Dugulan, A.I.; Ruitenbeek, M.; de Jong, K.P. Size and Promoter Effects on Stability of Carbon-Nanofiber-Supported Iron-Based Fischer-Tropsch Catalysts. ACS Catal. 2016, 6, 4017-4024. [CrossRef]

74. Wang, H.W.; Lu, J.L. A review on particle size effect in metal-catalyzed heterogeneous reactions. Chin. Chem. 2020, 38, 1422-1444. [CrossRef]

75. Kang, J.; Deng, W.P.; Zhang, Q.H.; Wang, Y. Ru particle size effect in Ru/CNT-catalyzed Fischer-Tropsch synthesis. J. Energy Chem. 2013, 22, 321-328. [CrossRef] 